\author{
KATARZYNA BZDEGA ${ }^{1}$, BARBARA FOJCIK ${ }^{1}$, IZABELA GEROLD-ŚMIETAŃSKA ${ }^{1}$, \\ ADAM ROSTAŃSKI ${ }^{1}$, BARBARA TOKARSKA-GUZIK ${ }^{1}$, DOMINIK CHŁOND ${ }^{2}$, \\ JOWITA DROHOJOWSKA ${ }^{2}$, JACEK GORCZYCA ${ }^{2}$, MAŁGORZATA KALANDYK- \\ KOŁODZIEJCZYK ${ }^{2}$, ANNA CIEPLOK ${ }^{3}$, ADRIANNA KACZOROWSKA ${ }^{3}$, \\ MARIOLA KRODKIEWSKA ${ }^{3}$, ANETA SPYRA ${ }^{3}$
}

\author{
Uniwersytet Ślaski, \\ Wydział Nauk Przyrodniczych \\ Instytut Biologii $i$ Ochrony Środowiska \\ ${ }^{1}$ Zespót Botaniki $i$ Ochrony Przyrody \\ Jagiellońska 28, 40-032 Katowice \\ ${ }^{2}$ Zespół Zoologii \\ Bankowa 9, 40-007 Katowice \\ ${ }^{3} Z$ Zespół Hydrobiologii \\ Bankowa 9, 40-007 Katowice \\ E-mail: katarzyna.bzdega@us.edu.pl \\ barbara.fojcik@us.edu.pl \\ izabela.gerold-smietanska@us.edu.pl \\ adam.rostanski@us.edu.pl \\ barbara.tokarska-guzik@us.edu.pl \\ dominik.chlond@us.edu.pl \\ jowita.drohojowska@us.edu.pl \\ jacek.gorczyca@us.edu.pl \\ malgorzata.kalandyk@us.edu.pl \\ anna.cieplok@us.edu.pl \\ adrianna.koczorowska@us.edu.pl \\ mariola.krodkiewska@us.edu.pl \\ aneta.spyra@us.edu.pl
}

\title{
KOLEKCJE I DANE PRZYRODNICZE INSTYTUTU BIOLOGII, BIOTECHNOLOGII I OCHRONY ŚRODOWISKA UNIWERSYTETU ŚLĄSKIEGO W KATOWICACH
}

\section{WPROWADZENIE}

Rozwój kolekcji i baz danych dotyczących przyrody ożywionej na Uniwersytecie Śląskim jest ściśle zwiazany $z$ ponad 50-letnia historia studiów biologicznych na tej uczelni. Wraz $z$ rozwojem struktury organizacyjnej, pierwotnie Instytutu Biologii, a następnie Wydziału Biologii i Ochrony Srodowiska (od 2020 r. Instytutu Biologii, Biotechnologii i Ochrony Środowiska), tworzyły się zespoły badawcze botaniczne i zoologiczne, które w ramach prowadzonych prac, a także indywidualnych zainteresowań pracowników naukowych, gromadziły zbiory i dane przyrodnicze stanowiace materiał badawczy $i$ doku- mentacyjny. Materiały te stały się zalążkiem dzisiejszych kolekcji. Gromadzone dane i zbiory pochodzily przede wszystkim $z$ badań prowadzonych na terenie regionu śląskiego i z czasem zostały wzbogacone o zbiory zebrane w innych regionach kraju, Europy i świata. Zbiory niektórych kolekcji zasilili naukowcy, którzy przenieśli się do ówczesnego Instytutu Biologii $z$ innych uniwersytetów. W taki sposób trafiła do zbiorów botanicznych, kolekcja roślin prof. Krzysztofa Rostańskiego, zebranych na gruzach Wrocławia po zakończeniu II wojny światowej.

Od początku istnienia Instytutu/Wydziału Biologii organizowano ekspedycje i obozy naukowe krajowe i zagraniczne, podczas

Słowa kluczowe: entomofauna, herbarium, kolekcje przyrodnicze, makrobezkręgowce słodkowodne, Uniwersytet Śląski

*Artykuł powstał dzięki wsparciu finansowemu z projektu POPC.02.03.01-00-0081/19 „Integracja i mobilizacja danych o różnorodności biotycznej Eukaryota w zasobach polskich instytucji naukowych” (IMBIO). 
których gromadzone były zbiory przyrodnicze w celu powiększania kolekcji naukowych, a także dla potrzeb dydaktyki i wystaw edukacyjnych organizowanych dla młodzieży. Pierwsza zagraniczna wyprawa naukowo-poznawcza „Biological Expedition to Middle East" została zorganizowana w 1974 r. Dwudziestu czterech uczestników wyprawy przemierzyło samochodem marki Star, wypożyczonym z Fabryki Samochodów Ciężarowych w Starachowicach, trasę około 14 tysięcy $\mathrm{km}$, wiodaca przez Turcję, Iran i Irak (NAWROT i NAKONIECZNY 2019). Kolejne wyprawy zorganizowano do Afryki Północnej i Zachodniej, w deltę Dunaju, w góry Peru i Boliwii, w dorzecze Amazonki, do Ekwadoru, Pakistanu i do Australii.

Kolekcje zgromadzone w Instytucie maja różny charakter. Część, głównie kolekcje zoologiczne, sa nadal rozproszone i pozostaja pod opieka zespołów badawczych lub pojedynczych osób, natomiast większość kolekcji botanicznych jest zdeponowana w Zielniku Naukowym Uniwersytetu Śląskiego (KTU).

Zielnik Naukowy Uniwersytetu Śląskiego rozpoczał działalność w 1972 r. Założycielem i inicjatorem powstania herbarium, jako jednostki naukowej, był prof. Krzysztof Rostański, pierwszy kurator Zielnika i długoletni kierownik Katedry Botaniki Systematycznej Wydziału Biologii i Ochrony Srodowiska, w strukturze której Zielnik funkcjonował kilkadziesiat lat. Pierwsze zbiory Zielnika stanowiła kolekcja ok. 20000 okazów roślin z Dolnego Śląska, będaca dokumentacją dotychczasowej pracy prof. Rostańskiego we Wrocławiu (ROSTAŃSKI i KRAWCZYK 1993). Obecnie, majac za soba niemal 50 lat istnienia, Herbarium Uniwersytetu Ślaskiego jest jedna $z$ młodszych tego typu kolekcji roślinnych w Polsce (ROSTAŃSKI i GEROLD-ŚMIETAŃSKA 2008).

W 1974 r. Zielnik Uniwersytetu Śląskiego został zgłoszony do międzynarodowego wykazu zielników naukowych świata - „Index Herbariorum", uzyskujac unikatowy akronim KTU, którym oznaczony jest do dzisiaj.

Do końca XX w. zasoby Zielnika systematycznie powiększały się, aż do wyczerpania możliwości lokalowych budynku Wydziału Biologii i Ochrony Srodowiska w Katowicach przy ul. Jagiellońskiej. W 2001 r., dzięki uzyskanemu dofinansowaniu grantowemu z Komitetu Badań Naukowych, zbiory zielnikowe przeniesiono do nowej siedziby - Pracowni Dokumentacji Botanicznej i Zielnika Naukowego na terenie Kampusu Uniwersytetu Śląskiego w Chorzowie, która funkcjonuje do dziś jako nowoczesna placówka naukowa, odpowiadajaca standardom europejskim (Ryc. 1). W tym samym roku kierownictwo Pracowni Dokumentacji Botanicznej i Zielni-

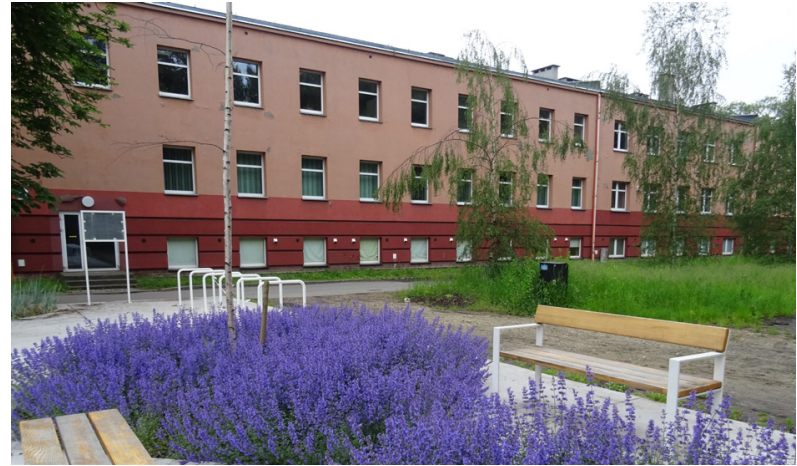

Ryc. 1. Budynek na terenie Kampusu Uniwersytetu Śląskiego w Chorzowie, w którym mieści się Pracownia Dokumentacji Botanicznej i Zielnik Naukowy (KTU) (fot. Adam Rostański).

kiem Naukowym (KTU), obją dr hab. Adam Rostański. Obecnie kuratorem kolekcji roślin naczyniowych jest dr Izabela Gerold-Śmietańska.

W dniu 16 października 2018 r., w ramach obchodów 50-lecia istnienia Wydziału Biologii i Ochrony Środowiska na Uniwersytecie Ślaskim, odbyła się uroczystość nadania Pracowni Dokumentacji Botanicznej i Zielnikowi Naukowemu Uniwersytetu Ślaskiego $\mathrm{w}$ Katowicach imienia prof. dr hab. Krzysztofa Rostańskiego - założyciela i twórcy Zielnika Naukowego KTU (Ryc. 2).

Potrzeba uporzadkowania rozproszonej wiedzy o przyrodzie ożywionej (a także nieożywionej) regionu ślasskiego stała się bodźcem do stworzenia regionalnego systemu informacji $\mathrm{i}$ baz danych o środowisku (ToKARSKA-GUZIK i współaut. 2015). Zadanie to podjęto w ramach projektu pt. „Ogólnodostępna baza danych bio- i georóżnorodności Województwa Śląskiego - integralna część Otwartego Regionalnego Systemu Informa-

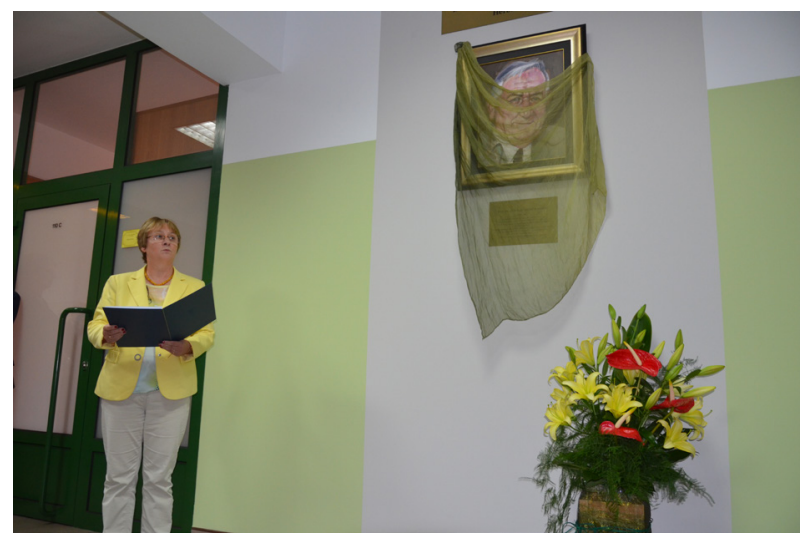

Ryc. 2. Nadanie Zielnikowi Naukowemu KTU imienia prof. dr. hab. Krzysztofa Rostańskiego założyciela i twórcy kolekcji (fot. Barbara Tokarska-Guzik). 
cji Przestrzennej, BIOGEO SILESIA ORSIP", który był realizowany w latach 2011-2015, w ramach Regionalnego Programu Operacyjnego Województwa Śląskiego. Projekt został zrealizowany w ramach Regionalnego Programu Operacyjnego Województwa Śląskiego, Priorytet V Środowisko RPO WSL. Działanie 5.4. Zarzadzanie środowiskiem; typ projektu - Tworzenie i rozwój regionalnych systemów informacji i baz danych dotyczacych stanu środowiska, pod warunkiem powszechnego do nich dostępu (więcej informacji na stronie http://biogeo.us.edu.pl/). Utworzona w ramach projektu Ogólnodostępna Baza Danych (OBD) obejmuje zakres informacyjny zwiazany z 18 zbiorami danych dotyczacymi różnorodności biologicznej i $z$ jednym zbiorem o geostanowiskach województwa śląskiego (TOKARSKA-GUZIK i współaut. 2015). W bazie tej znalazły się dane pochodzace $z$ badań naukowych poświęconych roślinom naczyniowym, mszakom, wybranym grupom zwierząt bezkręgowych i kręowcow, w tym także część danych udokumentowanych w formie kolekcji (np. baza tematyczna: „Stanowiska gatunków roślin naczyniowych udokumentowane okazami zielnikowymi wraz $\mathrm{z}$ ilustracją graficzna”).

Od 2018 r. w Instytucie Biologii, Biotechnologii i Ochrony Środowiska realizowany jest projekt pn. "Cyfrowa Entomologiczna Baza Danych HEMIPTERON (CEBD HEMIPTERON)", współfinansowany ze środków Europejskiego Funduszu Rozwoju Regionalnego, w ramach osi priorytetowej II. Cyfrowe ślaskie. Celem projektu jest digitalizacja kolekcji entomologicznej pluskwiaków i zabezpieczenie zbiorów w formie cyfrowej oraz upublicznienie bazy po zakończeniu projektu w 2021 r. Bogata kolekcja pluskwiaków gromadzona od 50 lat przez naukowców $z$ Katedry/Zespołu Zoologii Uniwersytetu Śląskiego zdeponowana jest na szpilkach entomologicznych w specjalnych gablotach, w postaci preparatów mikroskopowych lub inkluzji w bursztynie. Pomysłodawca i koordynatorem projektu jest prof. dr hab. Karina Wieczorek z Zespołu Zoologii na Wydziale Nauk Przyrodniczych UŚ.

W ostatnich latach rozpoczęto intensywne opracowywanie zbiorów zielnika naukowego, katalogujac szczegółowo okazy utworzono jedna $z$ nielicznych w Polsce komputerowych baz danych, obejmujacych kolekcję okazów zielnikowych wraz $z$ danymi georeferencyjnymi. Baza jest udostępniania zainteresowanym pod nadzorem kuratora zielnika.

BARBARA TOKARSKA-GUZIK, ADAM ROSTAŃSKI, IZABELA GEROLDŚMIETAŃSKA

\section{ZAKRES KOLEKCJI/DANYCH}

\section{KOLEKCJE BOTANICZNE}

Zielnik Naukowy (Herbarium) KTU i Pracownia Dokumentacji Botanicznej Uniwersytetu Ślaskiego w Katowicach

Zielniki (Herbaria), jako archiwalne kolekcje okazów roślinnych, są obecnie częścią instytucji naukowo-badawczych zajmujacych się botanika. Funkcjonuja zazwyczaj przy szkołach wyższych, instytutach badawczo-rozwojowych, ogrodach botanicznych czy muzeach przyrodniczych. Przetrzymywane i konserwowane tam rośliny stanowią ważny materiał do badań naukowych (taksonomicznych, genetycznych, filogenetycznych), będac źródłem informacji na temat rozmieszczenia gatunków roślin na świecie czy zmian szaty roślinnej na przestrzeni lat.

Aktualnie kolekcję Zielnika Naukowego Uniwersytetu Śląskiego (KTU), liczaca ponad 140000 arkuszy zielnikowych roślin naczyniowych, tworzą głównie okazy dokumen-

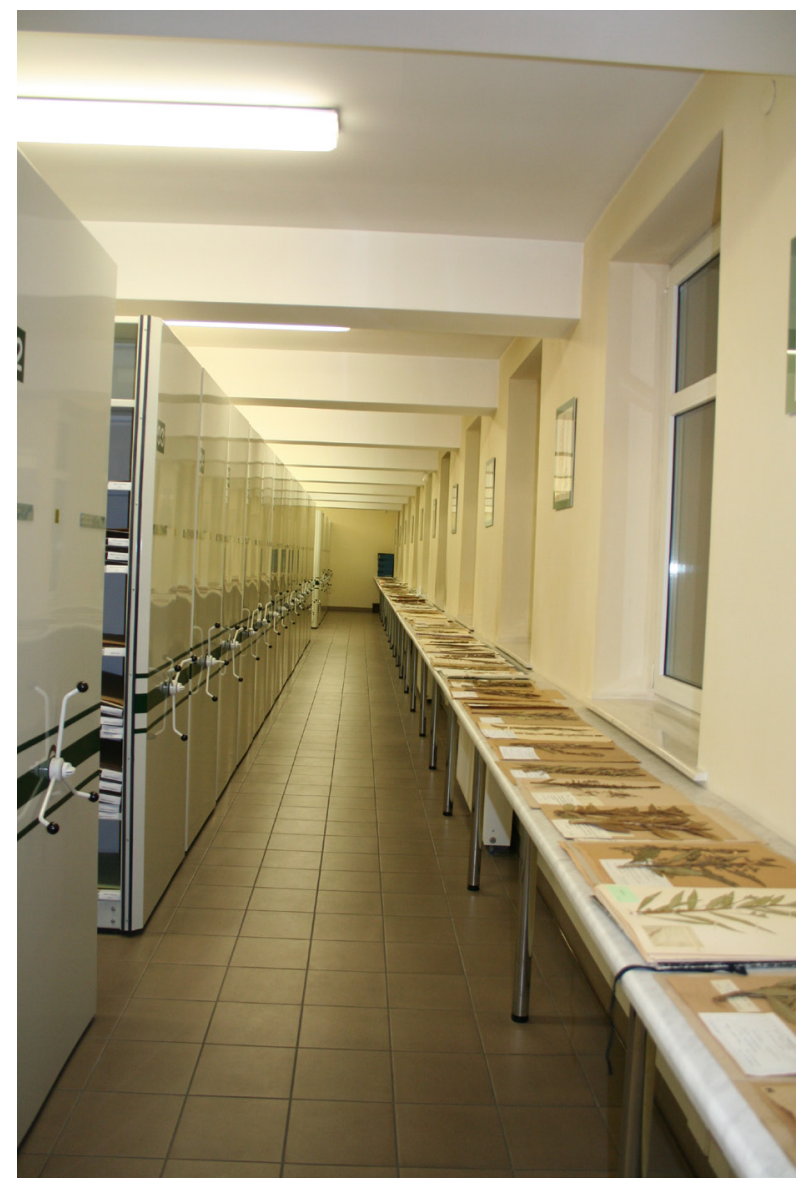

Ryc. 3. Jedno $z$ pomieszczeń Zielnika Naukowego Uniwersytetu Śląskiego (KTU) (fot. Adam Rostański). 


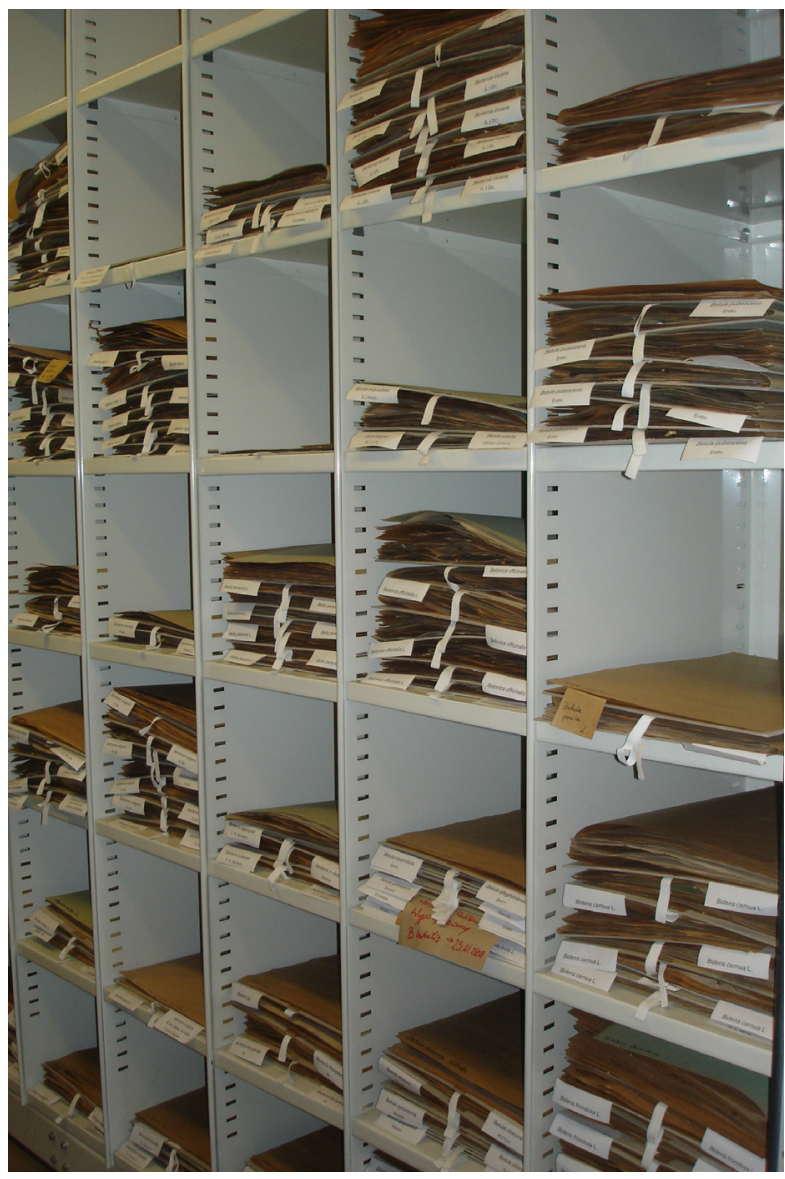

Ryc. 4. Składki $z$ okazami zielnikowymi przechowywane w kompaktowych szafach jezdnych (fot. Adam Rostański).

tujące wyniki projektów badawczych, prac doktorskich i magisterskich, stanowiace jednocześnie obszerną i cenną dokumentacje współczesnej flory Górnego Śląska oraz innych obszarów kraju i świata (Ryc. 3 i 4).

Do wyróżniających się i cennych kolekcji Zielnika Naukowego KTU należy, jeden z największych i najbardziej znanych w Europie, zbiór roślin $z$ rodzaju wiesiołek Oenothera L., liczacy ponad 12000 arkuszy zielnikowych, który obejmuje m.in. typy nomenklatorycze opisanych taksonów wiesiołka, w tym: holotypy, izotypy, paratypy i lektotypy. Kolekcja powstała dzięki, rozwijanym przez ponad 40 lat, zainteresowaniom naukowym prof. Krzysztofa Rostańskiego, koncentrującym się przede wszystkim na taksonomii i fitogeografii roślin $z$ rodzaju wiesiołek (Oenothera L.) (Ryc. 5 i 6).

Geograficzny obszar pochodzenia zbiorów Zielnika Naukowego KTU to głównie Polska i Europa, ale także Ameryka Północna, Środkowa (Kuba) i Południowa oraz Afryka, Azja (Syberia, Bliski Wschód, Jemen), Australia i Arktyka. Najstarsze zbiory pochodza $z$ XIX

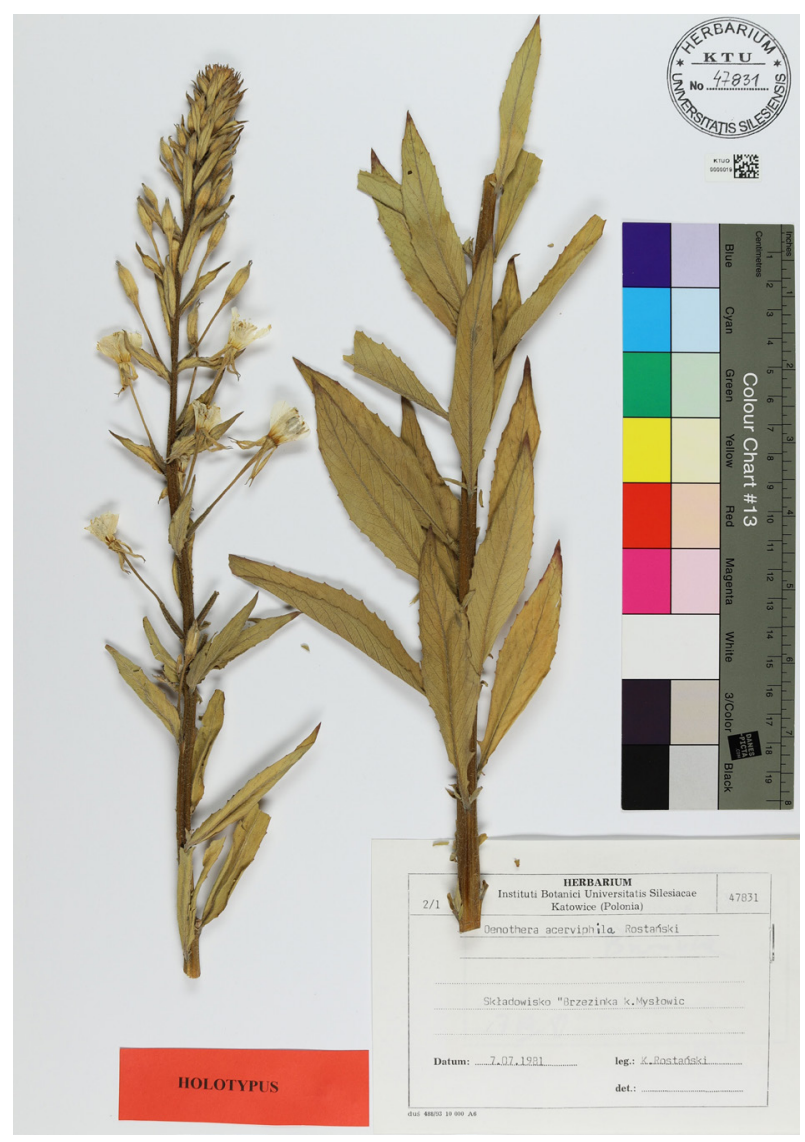

Ryc. 5. Holotyp gatunku - wiesiołek zwałowy Oenothera acerviphila Rostański (fot. Adam Rostański).

w. (lata 1880-1890), a najnowsze wzbogacają kolekcje na bieżąco.

Cenne kolekcje reprezentowane w zbiorach Zielnika Naukowego KTU i ich autorzy, to m.in.:

- kolekcja przedstawicieli rodzaju Oenothera w Europie - Krzysztof Rostański;

- rośliny naczyniowe Kuby - Krzysztof Rostański;

- rośliny naczyniowe Jemenu - Abdul-

-Nasser Al Gifri;

- rośliny naczyniowe Górnego Śląska Andrzej Sendek, Andrzej Urbisz, Barbara Tokarska-Guzik, Teresa Nowak, Adam Rostański, Beata Babczyńska-Sendek, Alina Urbisz i in.;

- rośliny naczyniowe Ślasska Opolskiego -

Piotr Szotkowski;

- rośliny naczyniowe południowej Polski i Bliskiego Wschodu - Krzysztof Jędrzejko;

- rośliny naczyniowe Południowej Rosji, Ukrainy i Kaukazu - Krzysztof Rostański i Adam Rostański;

- rośliny naczyniowe $z$ terenu Polski, Francji, Kanady i Stanów Zjednoczonych Florian Celiński; 


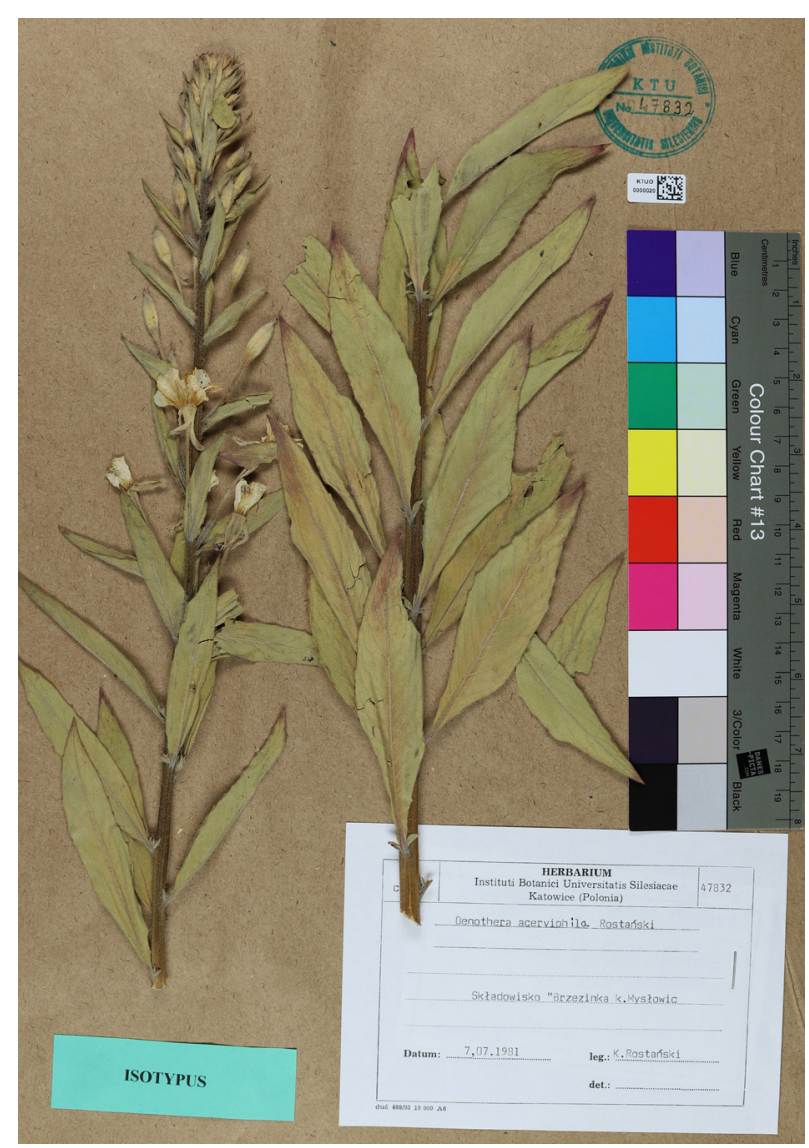

Ryc. 6. Okaz - izotyp gatunku - wiesiołek zwałowy Oenothera acerviphila Rostański (fot. Adam Rostański).

- rośliny naczyniowe Jury Krakowsko-Częstochowskiej i Syberii - Stanisław Wika;

- obce gatunki inwazyjne we florze Polski i Europy - Barbara Tokarska-Guzik;

- kolekcja storczykowatych Polski - Leszek Bernacki;

- rośliny naczyniowe Ziemi Chrzanowskiej i wybranych terenów południowej Polski - Piotr Grzegorzek;

- kolekcja roślin tundry arktycznej Spitsbergenu i Patagonii - Jerzy Zygmunt;

- kolekcja roślin tundry arktycznej Islandii - Paweł Wassowicz (Ryc. 7 i 8).

Kolekcje zwiąane $z$ realizowanymi kierunkami badań w ośrodku katowickim:

- Flora Górnego Śląska i terenów przyległych (Ryc. 9 A, B, C);

- Chronione i zagrożone gatunki roślin w Polsce;

- Taksonomia i chorologia wybranych taksonów flory naczyniowej: rodzina wiesiołkowatych (Onagraceae), kozłkowatych (Valerianaceae), wilczomleczowatych (Euphorbiaceae), storczykowatych (Orchidaceae), traw (Poaceae), złożonych (Asteraceae) i in.;

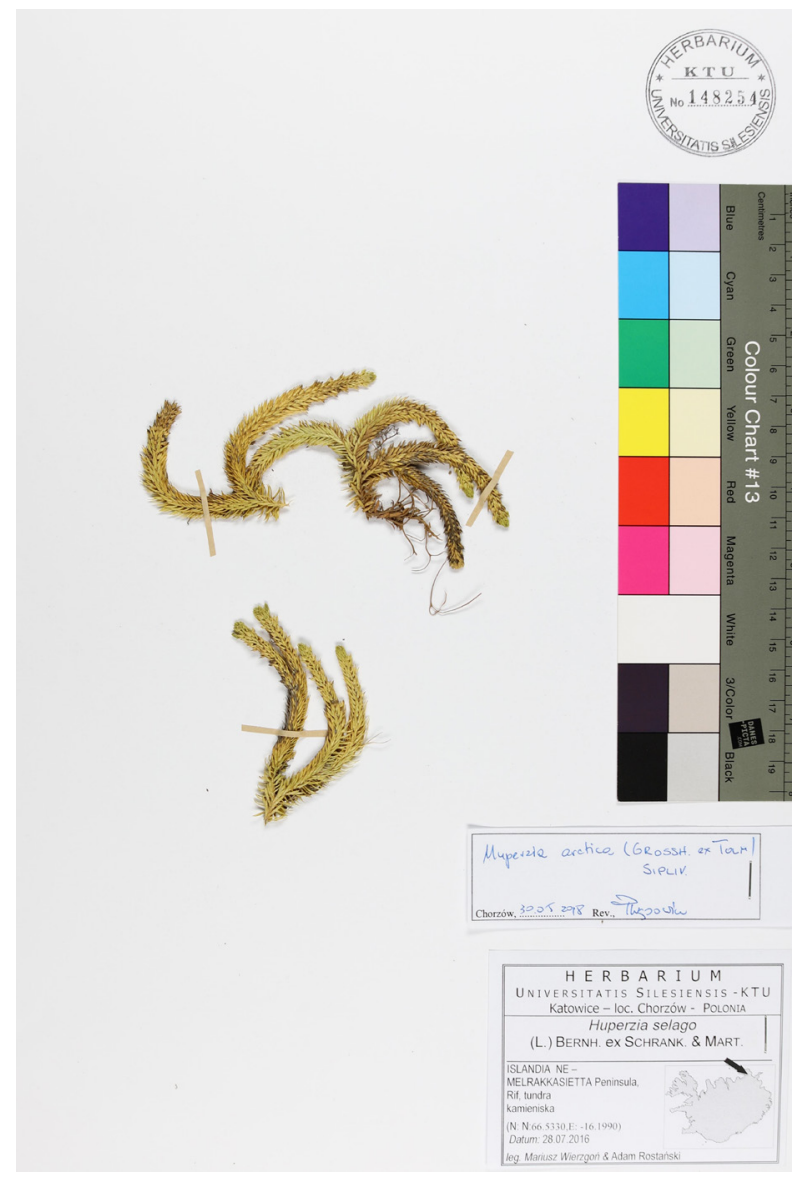

Ryc. 7. Wroniec arktyczny Huperzia arctica (Tolm.) Sipliv. - okaz pochodzacy $z$ Islandii (fot. Adam Rostański).

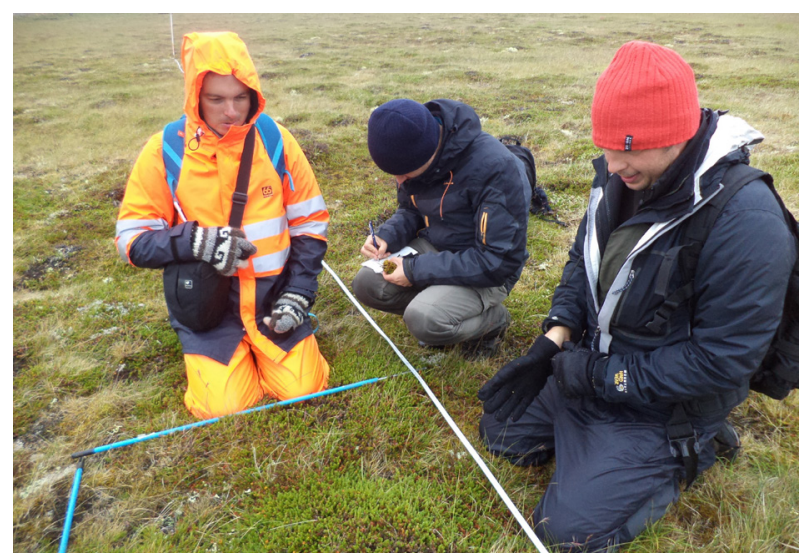

Ryc. 8. Zbiór dokumentacji botanicznej w tracie badań w Północnej Islandii (rok 2017). Na zdjęciu: dr Paweł Wąsowicz, dr Andrzej Pasierbiński, mgr Mariusz Wierzgoń (fot. Adam Rostański).

- Obce gatunki inwazyjne, kenofity i efemerofity Polski;

- Rośliny siedlisk metalonośnych Polski i Europy (Ryc. 9D). 

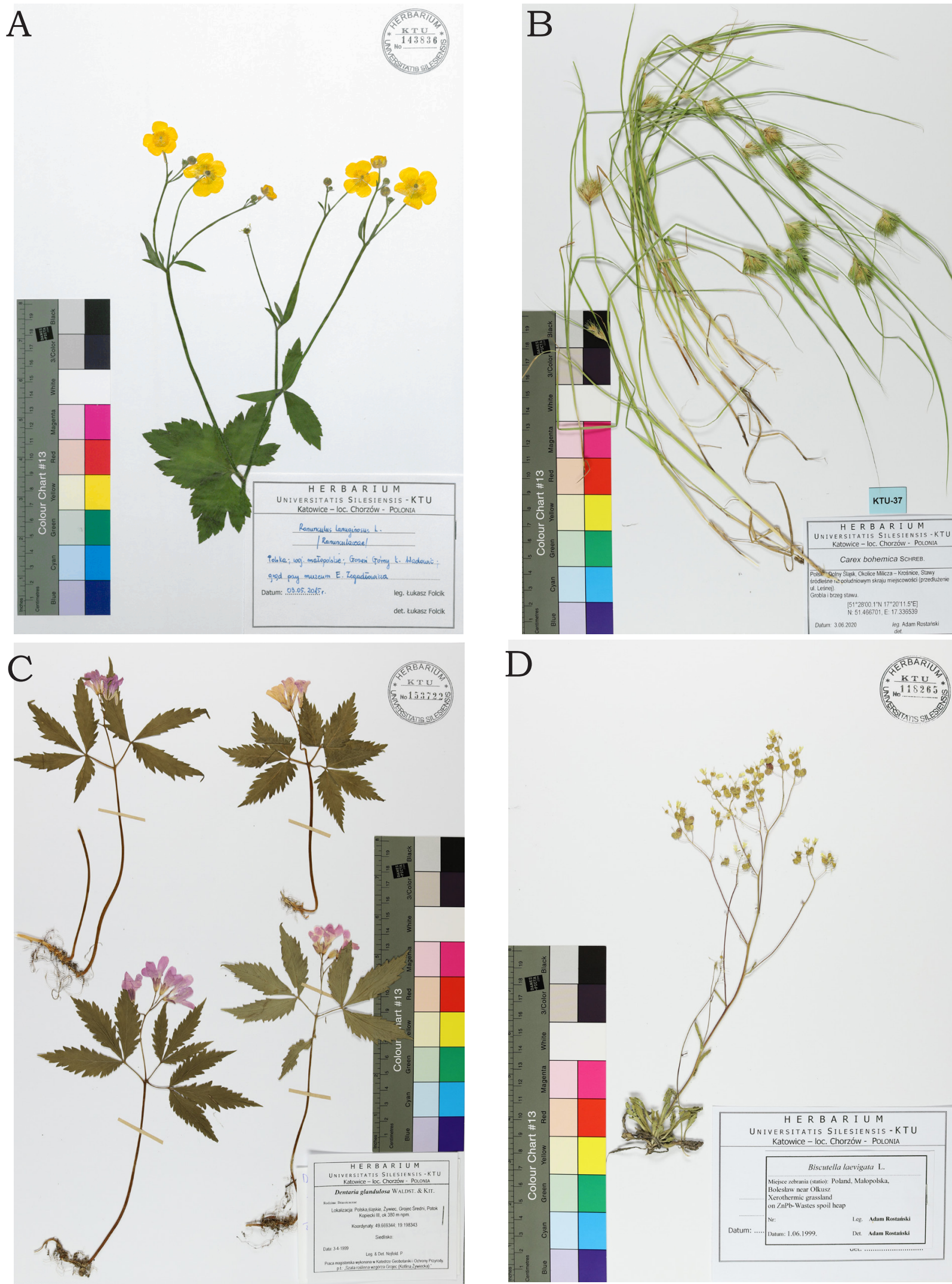

$\mathrm{D}$
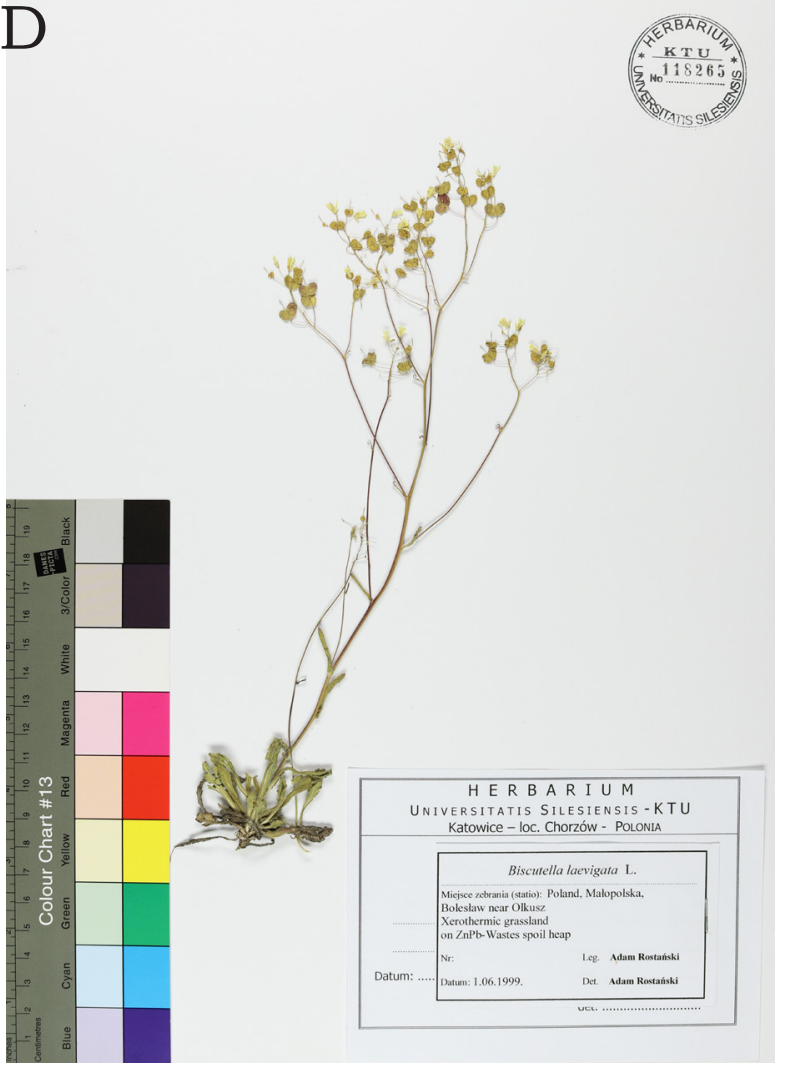

Ryc. 9. Wybrane okazy zielnikowe z Zielnika Naukowego Uniwersytetu Ślaskiego (KTU). A. Jaskier kosmaty Ranunculus lanuginosus L. B. Żywiec gruczołowaty Dentaria glandulosa Waldst. \& Kit. C. Turzyca ciborowata Carex bohemica Schreb. D. Pleszczotka górska Biscutella laevigata L. (fot. Adam Rostański). 

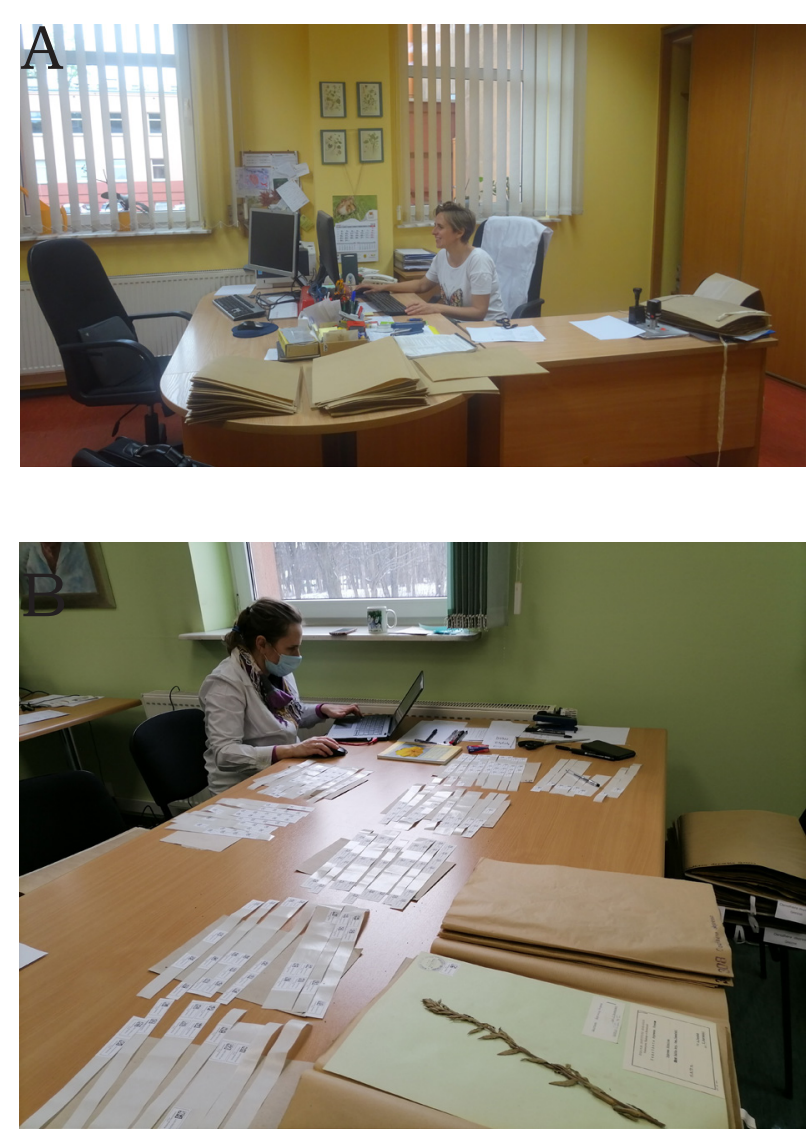

Ryc. 10 A, B. Opracowywanie zbiorów (digitalizacja) w Zielniku Naukowym Uniwersytetu Śląskiego (KTU) (fot. Adam Rostański).

\section{Zielnik briologiczny (KTU-B)}

Odrębną kolekcję Zielnika Naukowego Uniwersytetu Ślaskiego stanowi zielnik briologiczny (KTU-B), którego kuratorem jest dr hab. Barbara Fojcik. Kolekcja zielnika briologicznego mieści się w budynku Instytutu Biologii, Biotechnologii i Ochrony Środowiska, w Katowicach, przy ul. Jagiellońskiej 28. Zbiór ten aktualnie obejmuje ponad

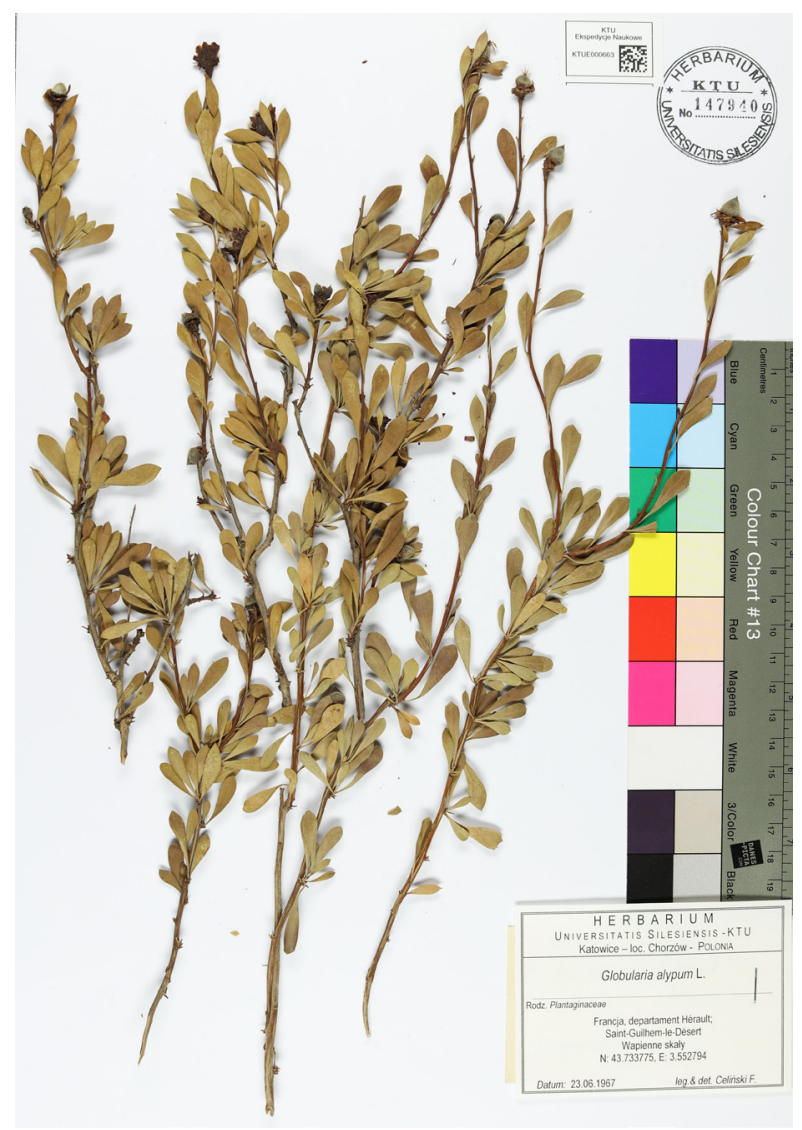

Ryc. 11. Przykładowa fotografia okazu kulnika Globularia alypum L. IMBIO KTUE 000663 (fot. Adam Rostański).

23000 torebek i systematycznie się rozrasta. Materiały zielnikowe pochodza przede wszystkim $z$ obszaru Polski, głównie $z$ Wyżyny Wieluńskiej, Wyżyny Krakowsko-Częstochowskiej i Wyżyny Śląskiej (zbiory B. Fojcik). Pojedyncze okazy zebrano poza granicami kraju, m.in. w Chorwacji, na Słowacji, na Ukrainie i w Wielkiej Brytanii.

Tabela 1. Kolekcje botaniczne lub ich części zdeponowane w Zielniku Naukowym KTU; opracowanie w ramach projektu IMBIO $z$ przeznaczeniem do udostępnienia.

\begin{tabular}{llr}
\hline Nazwa kolekcji & Akronim kolekcji & Liczba okazów \\
\hline Flora Kuby (KTU-Cuba) & KTUC & 1700 \\
Wiesiołek Oenothera (KTU-Oenothera) & KTUO & 10500 \\
Baza Paprotniki i nagonasienne (Pteridophyta - Pinophyta) (KTU- Pterido- KTUP & 800 \\
phyta-Pinophyta) & & 100 \\
Gatunki z rodzaju jeżyna Rubus w wyspach leśnych (KTU-Generale) & KTUG & 1000 \\
Kolekcja roślin - Flora Jemenu (KTU-Yemen) & KTUY & 2000 \\
Rośliny naczyniowe obcego pochodzenia (KTU-Alien) & KTUA & 1000 \\
Wyprawa Naukowa North Africa '88 (KTU-Expedition) & KTUE & 46000 \\
Kolekcja roślin naczyniowych Europy (KTU-Europe) & KTU-B & 6000 \\
Kolekcja mchów (KTU-Bryophyta) & & \\
\hline
\end{tabular}




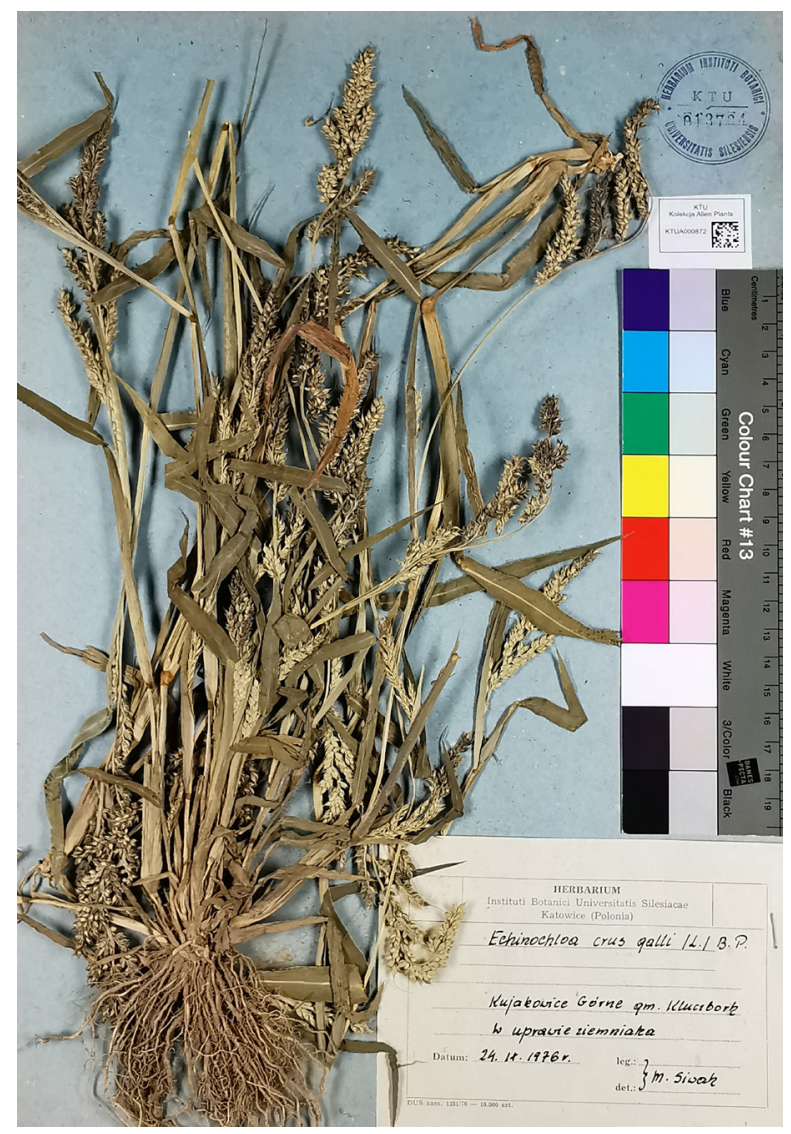

Ryc. 12. Przykładowa fotografia alegatu Echinochloa crus-galli (L.) P.Beauv. IMBIO KTUA 000872 (fot. Katarzyna Bzdęga).

Zgodnie $z$ idea współczesnych kolekcji naukowych, celem ich działalności nie jest jedynie gromadzenie $\mathrm{i}$ przechowywanie zbiorów, ale udostępnianie i upowszechnianie tej informacji szerokiemu gronu zainteresowanych odbiorców w kraju i na świecie. Od kilkunastu lat Zielnik Naukowy Uniwersytetu Śląskiego (KTU) jest członkiem Krajowej Sieci Informacji o Bioróżnorodności (KSIB), będącej częścia międzynarodowej organizacji, koncentrującej się na udostępnianiu danych dotyczących różnorodności biologicznej (ang. Global Biodiversity Information Facility, GBIF). Aktywne uczestnictwo Zielnika Naukowego Uniwersytetu Ślaskiego w programach udostępniania zbiorów wymusza potrzebę stałego rozwoju i konieczność dostosowywania informacji w bazach, zwiększając tym samym otwartość jednostki i dając możliwość korzystania $z$ zasobów kolekcji zielnikowych na odległość (wirtualne herbarium), co $z$ kolei przyczynia sie do wzmacniania roli naukowo-edukacyjnej Zielnika w regionie i na świecie.

Kolekcja botaniczna opracowywana w ramach projektu „Integracja i mobilizacja danych o różnorodności biotycznej Eukaryota

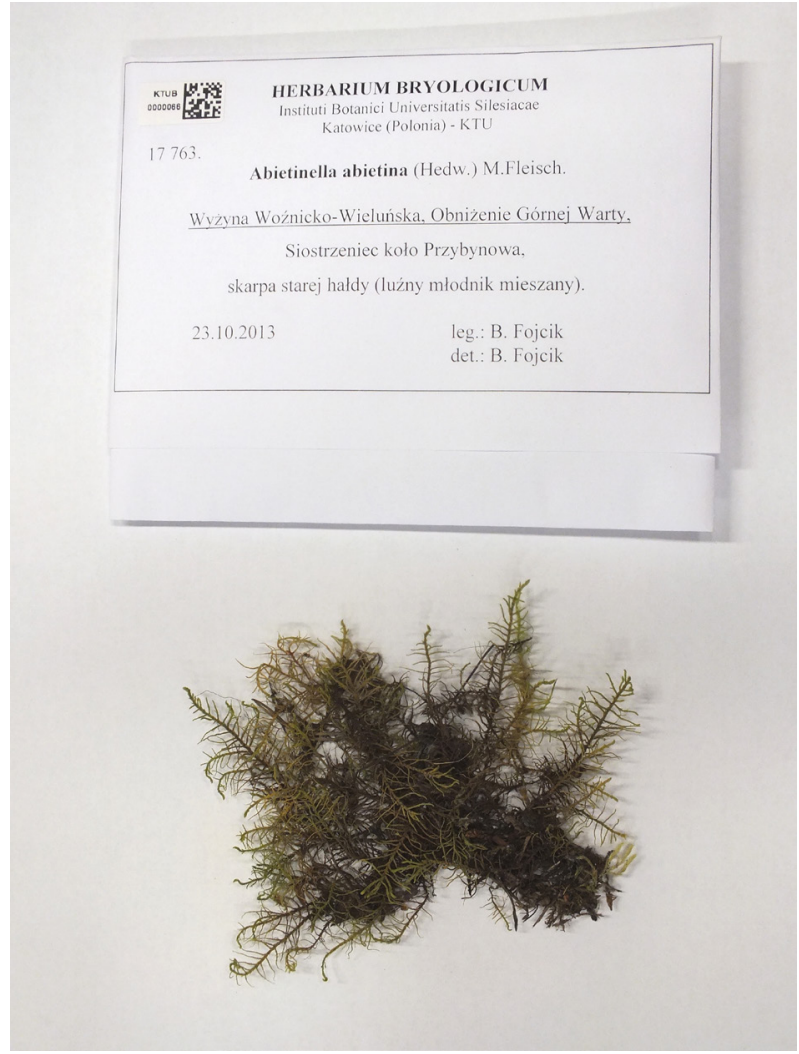

Ryc.13. Przykładowa fotografia alegatu Abietinella abietina (Hedw.) M.Fleisch. IMBIO KTUB 000066 (fot. Barbara Fojcik).

w zasobach polskich instytucji naukowych (IMBIO)".

W ramach projektu IMBIO objęto opracowaniem wybrane kolekcje lub ich części zdeponowane w Zielniku Naukowym KTU (Ryc. 10A, B, 11 i 12). Łacznie zostanie zdigitalizowanych i udostępnionych 63100 rekordów, w tym następujace kolekcje (patrz Tabela 1).

Każdy z okazów (rekordów bazy) otrzymał unikatowy identyfikator, tzw. kod matryco-

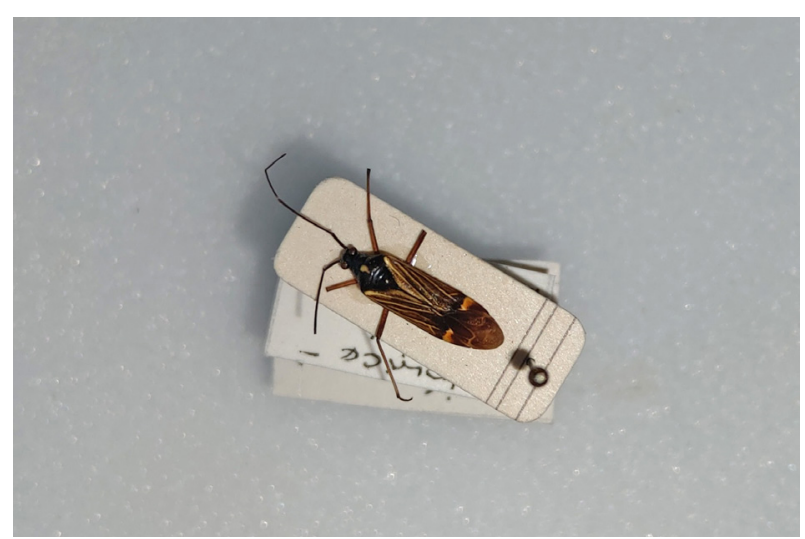

Ryc. 14. Miris striatus (L.) (fot. Jacek Gorczyca). 


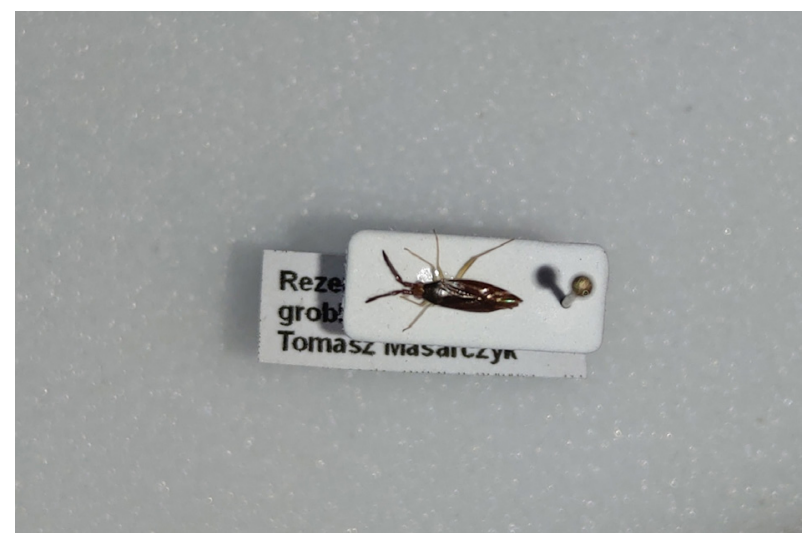

Ryc. 15. Heterotoma planicornis (Pall.) (fot. Jacek Gorczyca).

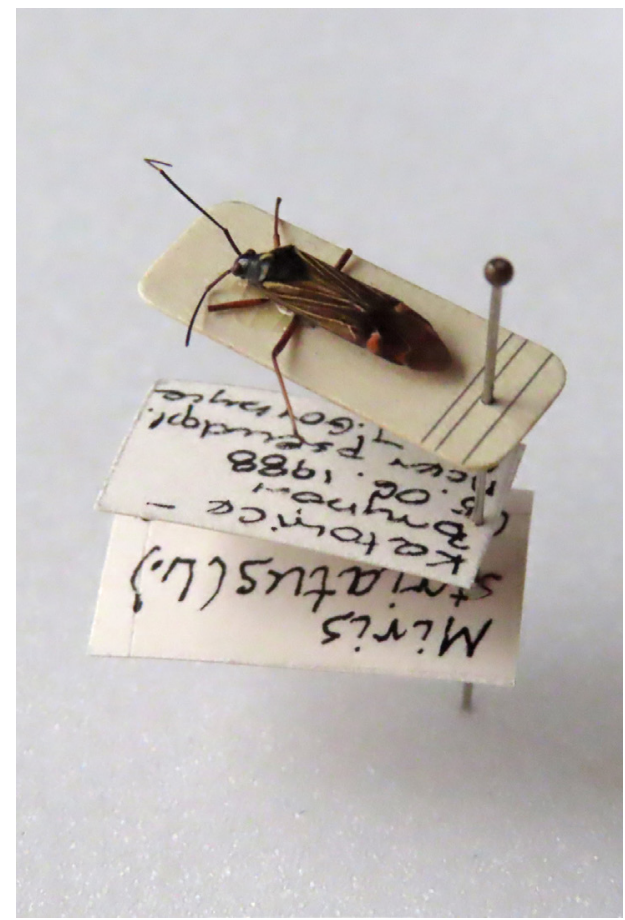

Ryc. 16. Miris striatus (L.) - sposób opisu pojedynczego okazu (fot. Jacek Gorczyca).

wy 2D [ang. Data Matrix (barecode)] i został scharakteryzowany na podstawie blisko 40 zdefiniowanych atrybutów. Dotycza one m.in. przynależności systematycznej (na różnych poziomach), lokalizacji (na różnych poziomach), daty zbioru i siedlisk, na których stwierdzono obecność danego okazu (biotop).

Do bazy IMBIO przekazano 6000 rekordów mchów z zielnika KTU-B (Ryc. 13). Obejmuja one 54 gatunki.

ADAM ROSTAŃSKI, IZABELA GEROLDŚMIETAŃSKA, BARBARA FOJCIK, KATARZYNA BZDEGA, BARBARA TOKARSKA-GUZIK

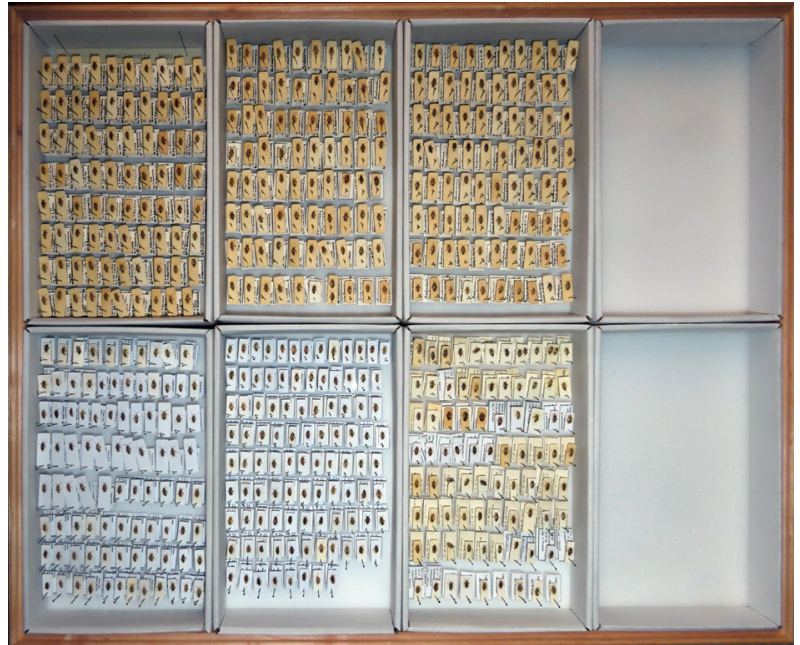

Ryc. 17. Kolekcja tasznikowatych w gablocie entomologicznej (fot. Jacek Gorczyca).

\section{KOLEKCJE ZOOLOGICZNE}

Kolekcja krajowych pluskwiaków z rodziny tasznikowatych (Heteropera: Miridae)

Tasznikowate sa najliczniejszą rodzina w obrębie pluskwiaków różnoskrzydłych (Hemiptera: Heteroptera). Liczba dotychczas opisanych gatunków wynosi około 12000. Największe zróżnicowanie taksonomiczne tej grupy obserwujemy w rejonach tropikalnych. W Polsce znanych jest dotąd ponad 270 gatunków. Sa to owady najczęściej drobnych i średnich rozmiarów (Ryc. 14, 15), stosunkowo ściśle związane bionomicznie $z$ poszczególnymi taksonami roślin. Zwykle maja jedno, czasami dwa pokolenia w roku i zimuja najczęściej w postaci jaja. Niektóre gatunki tasznikowatych to groźne szkodniki roślin, często przenoszace również chorobotwórcze patogeny. Inne $z$ kolei sa wykorzystywane w szklarniach do zwalczania mszyc, maczlików, koliszków i innych szkodników roślin. Rodzina tasznikowatych dzielona jest tradycyjnie na 7 lub 8 podrodzin, $z$ których 6 występuje w Polsce, a 5 reprezentowanych jest w kolekcji Instytutu Biologii, Biotechnologii i Ochrony Środowiska.

Podstawowa metodą zbioru pluskwiaków $z$ rodziny tasznikowatych jest czerpak entomologiczny. Dodatkowo stosuje się także parasol entomologiczny, pułapki Barbera, żółte szalki czy pułapki świetlne oraz przeglądanie roślin, na których występuja. Poszczególne osobniki sa naklejane na kartoniki, opisywane, oznaczane i umieszczane na szpilkach entomologicznych (Ryc. 16). W przypadku niektórych, trudnych do oznaczania taksonów, preparowane sa ich segmenty genitalne (samicze i samcze), które podkleja się pod okazami lub przechowuje osobno na 

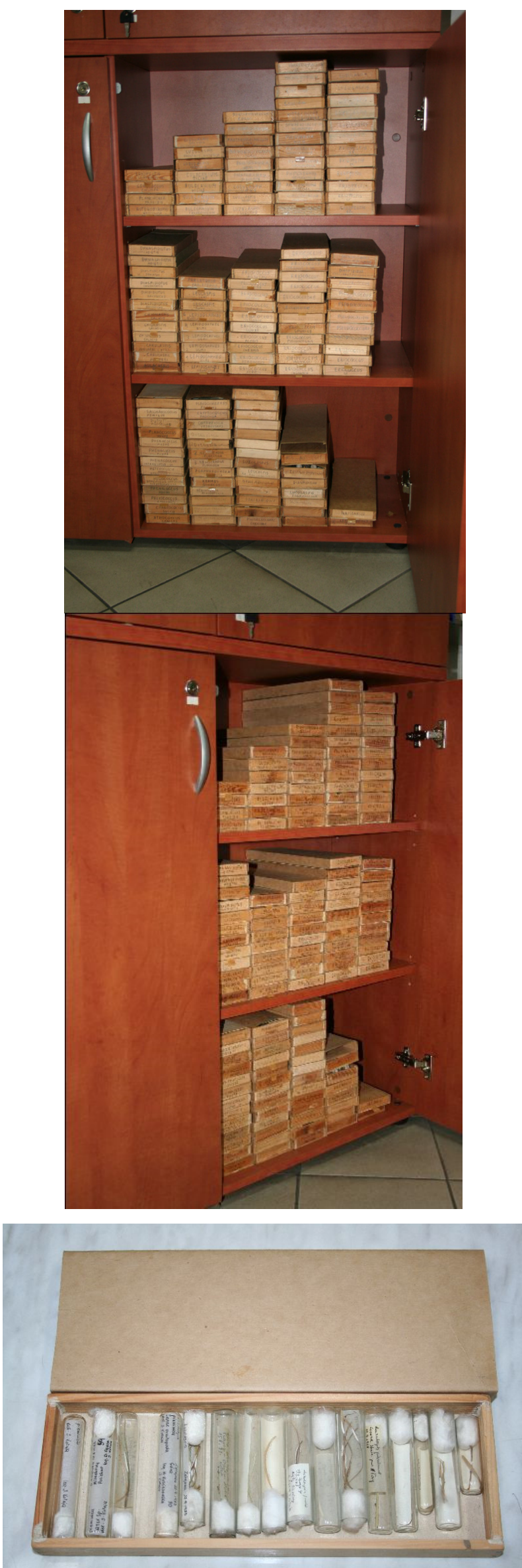

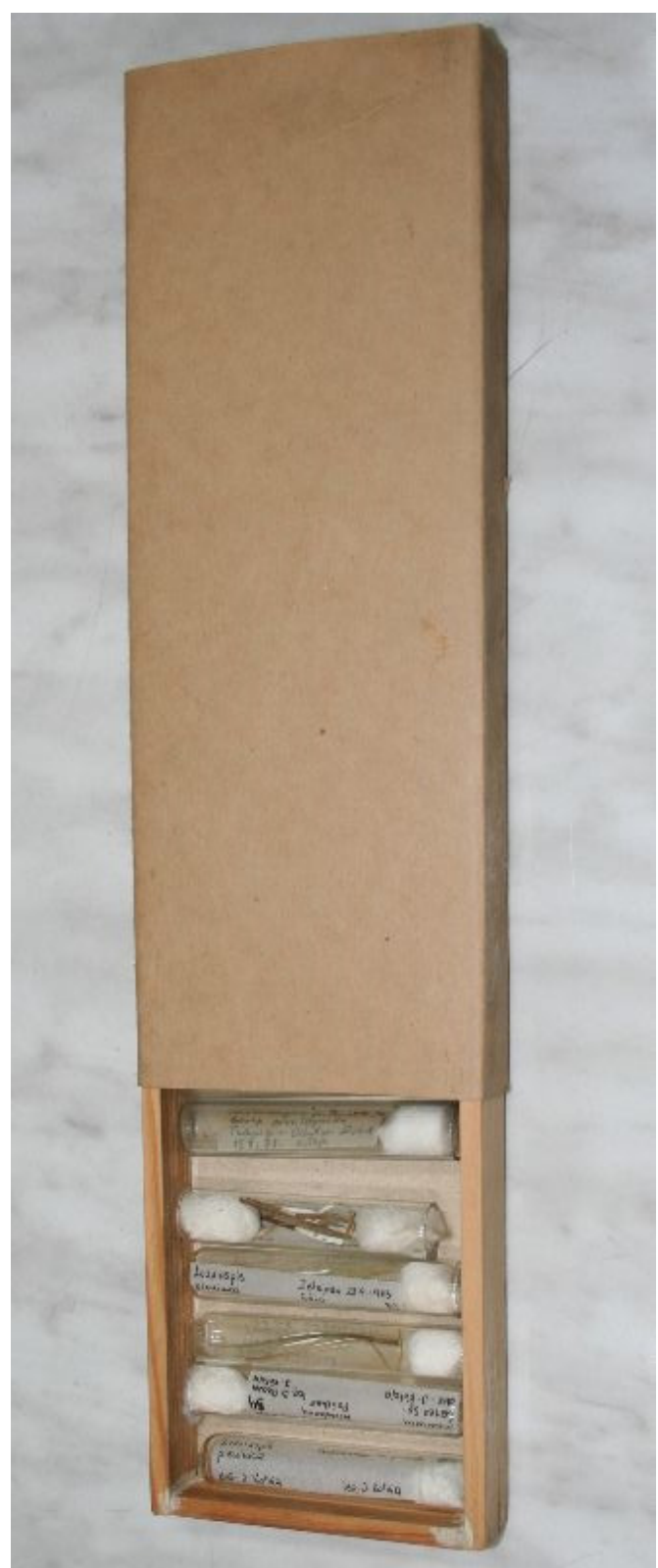

Ryc. 18-21. Sposoby przechowywania kolekcji czerwców (fot. Małgorzata Kalandyk-Kołodziejczyk).

szpilkach entomologicznych w specjalnych pojemniczkach. Gatunki $z$ poszczególnych podrodzin umieszczane sa alfabetycznie, na tackach w gablotach entomologicznych (Ryc. 17).

Kolekcja rodziny Miridae, pierwotnie gromadzona była w Zakładzie Zoologii Systematycznej i Biocenologii (późniejszej Katedrze Zoologii) Uniwersytetu Sląskiego. Jest ona stosunkowo młoda. Pierwsze okazy zostały zebrane i zdeponowane $\mathrm{w}$ zbiorze w latach 70. ubiegłego wieku przez prof. (wówczas magistra) Aleksandra Herczka. Pozyskano je w trakcie badań zoocenotycznych prowadzonych w pobliżu Huty Katowice, w okolicach Pińczowa i w czasie badań fau- 
nistycznych na Bagnach Biebrzańskich. W tych ostatnich brali także udział uczestnicy studenckiego obozu zoologicznego. Znaczne wzbogacenie kolekcji nastapiło na począt$\mathrm{ku}$ lat 80. XX w. Zbierano tasznikowate w czasie obozów zoologicznych organizowanych przez Katedrę Zoologii w okolicach Kalisza Pomorskiego. Opiekunem naukowym obozów był Aleksander Herczek, ale duży wkład w powiększanie zbioru i oznaczanie materiału wniósł również, będacy wówczas studentem, dr hab. Mirosław Nakonieczny. W następnych latach kolekcja była systematycznie wzbogacana przez materiały zbierane w trakcie badań faunistycznych w różnych rejonach Polski (Bieszczady, Pustynia Błędowska, okolice Mielnika nad Bugiem, torfowiska wysokie południowej Polski). Wyniki tych badań były systematycznie publikowane. Dużą część kolekcji stanowią także okazy zebrane przez studentów w ramach obozów zoologicznych czy praktyk terenowych odbywanych w różnych rejonach Polski. Do zbioru były też włączane osobniki zebrane $\mathrm{w}$ trakcie realizowanych prac magisterskich i doktorskich. Pod koniec lat 80. kolekcja została wzbogacona o przedstawicieli Miridae z Wyżyny Krakowsko-Częstochowskiej, które były gromadzone w trakcie realizowanej wówczas pracy doktorskiej, przez prof. Jacka Gorczyce, sprawujacego nastepnie opiekę nad kolekcja tasznikowatych, ówczesnej Katedry Zoologii, przez kolejnych 30 lat. Zbiór został wówczas uzupełniony o gatunki rzadko lub nie występujące w Polsce, które autor kolekcji wymienia $z$ zaprzyjaźnionymi entomologami z Holandii, Francji, Finlandii czy Rosji. Kolejne prace doktorskie wykonywane w Ojcowskim Parku Narodowym przez Dominika Chłonda i w Beskidzie Niskim przez Artura Taszakowskiego znacznie powiększyły omawiana kolekcję. Globalne ocieplenie klimatu sprawiło, że na teren naszego kraju wnikają coraz częściej gatunki $z$ południa i zachodu Europy. Dzięki staraniom dr Artura Taszakowskiego kolekcja wzbogaciła się o przedstawicieli rodziny Miridae, którzy zostali wykazani $\mathrm{z}$ terenu Polski w ostatnich latach (Dreaeocoris flavilinea Costa, Dichrooscytus gustavi Josifov) lub byli wykazywani sporadycznie (Horistus orientalis (Gmelin). Krytyczna rewizja faunistyczna zgromadzonych zbiorów przeprowadzona przez Artura Taszakowskiego pozwoliła również na wyodrębnienie gatunków dotychczas nie wykazywanych w Polsce, takich jak Psallus montanus Josifov, Charagochilus spiralifer Kerzhner czy Acetropis longirostris Puton.

Kolekcja tasznikowatych jest częścia zbioru pluskwiaków różnoskrzydłych (Heteroptera), w znakomitej większości lądowych. Najczęściej sa to okazy zebrane na terenie naszego kraju. Do tej pory liczba zdeponowanych w kolekcji okazów $z$ rodziny tasznikowatych, pochodzacych $z$ terenu Polski, wynosi ponad 20 000, a reprezentuja one ponad 230 gatunków. Kolekcja nie jest jeszcze całkowicie zinwentaryzowana $i$ nie wszystkie okazy sa oznaczone. Do projektu IMBIO właczono 5000 okazów. Wśród zgromadzonych znajdują się gatunki bardzo rzadko odnotowywane na terenie Polski: Reuteria marqueti Puton, Globiceps juniperi Reuter, Heterocapillus tigripes (Mulsant), Odontoplatys bidentulus (Herrich-Schaeffer), Adelphocoris josifovi E. Wagner czy Campyloneura virgula (Herrich-Schaeffer). Wśród materiałów zebranych w naszym kraju nie ma okazów typowych.

Oprócz taksonów występujacych w Polsce kolekcja zawiera również gatunki pochodzące $z$ innych krajów Europy (Francja, Grecja, Holandia, Finlandia, Rosja, Czechy, Słowacja, Rumunia, Bułgaria). Nieliczna grupę stanowia także osobniki pochodzace $z$ rejonów Neotropikalnych, Afrotropikalnych, Orientu, Papui Nowej Gwinei i Nowej Zelandii. Okazy te zostały zebrane przez pracowników dawnej Katedry Zoologii i zaprzyjaźnionych entomologów podczas wypraw naukowych. Część gatunków pozyskano w ramach wymiany.

JACEK GORCZYCA

\section{Kolekcja czerwców}

Czerwce należa do nadrodziny Coccoidea w obrębie podrzędu Sternorrhyncha i rzędu Hemiptera. Światowa fauna tych owadów obejmuje blisko 8000 gatunków. W Polsce odnotowano do tej pory 138 gatunków reprezentujacych 16 rodzin (sa to gatunki występujace poza szklarniami).

Kolekcja czerwców zdeponowana w Instytucie Biologii, Biotechnologii i Ochrony Środowiska Wydziału Nauk Przyrodniczych Uniwersytetu Ślaskiego obejmuje preparaty suche przechowywane w szklanych fiolkach (ponad 2000 fiolek), preparaty mikroskopowe (około 9 300), inkluzje w bursztynach (około 1 300) i nieliczne okazy w alkoholu.

Najważniejszą część kolekcji stanowia okazy czerwców przekazane przez prof. Jana Koteję (1932-2004). Profesor Jan Koteja był wybitnym polskim czerwcologiem, który opublikował liczne prace naukowe poświęcone taksonomii, morfologii i biologii czerwców. Okazy przechowywane w stanie suchym zostały zebrane przez Profesora podczas badań terenowych prowadzonych w różnych regionach Polski, m.in. na Górnym Ŝląsku, w Górach Świętokrzyskich, na Wyżynie Krakowsko-Częstochowskiej i na Roztoczu. Czerwce zbierane były wraz $z$ fragmentem rośliny żywicielskiej i przechowywane w 

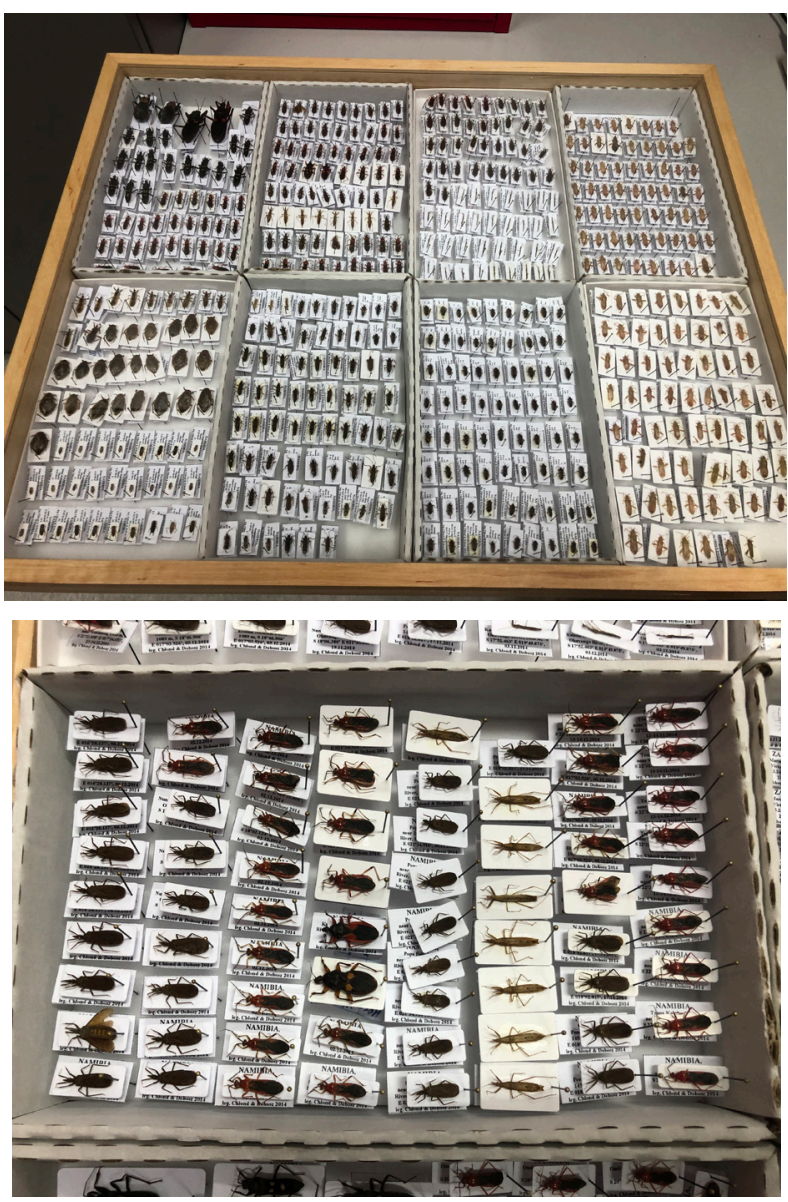
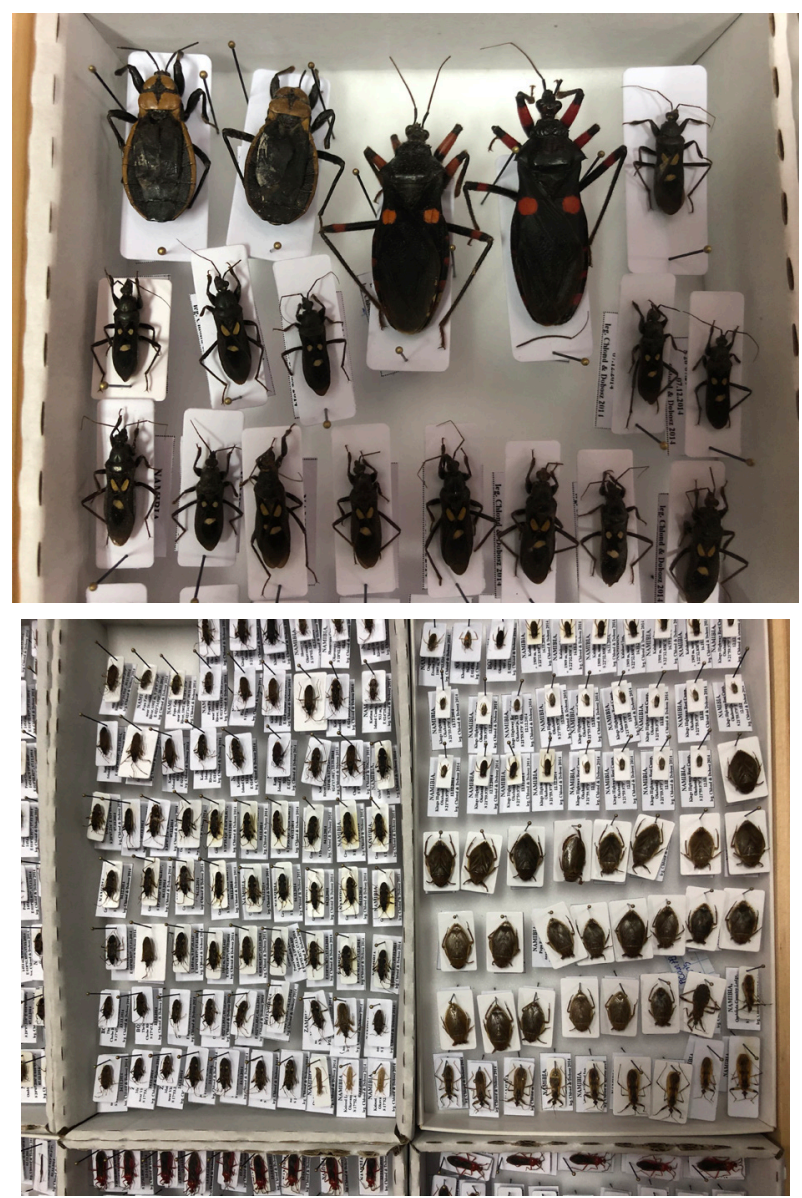

Ryc. 22-25. Kolekcja owadów pochodząca z Namibii (fot. Dominik Chłond).

szklanych fiolkach zawierajacych etykietę $z$ nazwa gatunkowa okazu, gatunkiem rośliny żywicielskiej, lokalizacja i data zbioru.

Preparaty mikroskopowe i okazy przechowywane w alkoholu, opracowane w ramach IMBIO, zostały zebrane i spreparowane przez dr Małgorzate Kalandyk-Kołodziejczyk. Preparaty mikroskopowe zawieraja pojedyncze okazy dorosłych samic lub stadiów larwalnych czerwców. Okazy zbierane były podczas prac terenowych prowadzonych w zróżnicowanych siedliskach południowej Polski, ze szczególnym uwzględnieniem muraw kserotermicznych i psammofilnych oraz zbiorowisk ruderalnych, a także w innych regionach kraju. Owady zostały zebrane również w czasie badań terenowych we Włoszech, w Czechach i na Słowacji.

Okazy przechowywane w alkoholu stanowią niewielką część kolekcji. Zawieraja dorosłe samice i larwy przede wszystkim $z$ rodzin Pseudococcidae i Coccidae (Ryc. 18-21).

Kolekcja opracowywana w ramach projektu IMBIO zawiera okazy reprezentujace łacznie 81 gatunków $z 12$ rodzin. Czerwce przechowywane w stanie suchym reprezen- tuja 72 gatunki z 12 rodzin. Preparaty mikroskopowe zawieraja okazy reprezentujace 50 gatunków należących do 10 rodzin. W ramach IMBIO zostanie opracowanych 1500 rekordów. Pojedynczy rekord to jeden preparat mikroskopowy lub jedna fiolka zawierajaca materiał przechowywany w stanie suchym (w jednej fiolce znajduja się liczne okazy, często tak małych rozmiarów, że niemożliwe jest ich policzenie).

W kolekcji znajduja się okazy gatunków czerwców odgrywających szczególna rolę w życiu człowieka, np. czerwiec polski (Porphyrophora polonica). Pozyskiwano $z$ niego cenny czerwony barwnik używany m.in. do farbowania tkanin i produkcji kosmetyków. Gatunek ten dawniej występował pospolicie na terenie Polski. Badania prowadzone przez ostatnie kilkanaście lat wykazały zanik populacji czerwca polskiego na większości dotychczasowych stanowisk. Drastyczne zmniejszenie liczebności tego gatunku związane jest głównie $z$ degradacjac siedlisk, przede wszystkim muraw psammofilnych.

MAŁGORZATA KALANDYK-KOŁODZIEJCZYK 

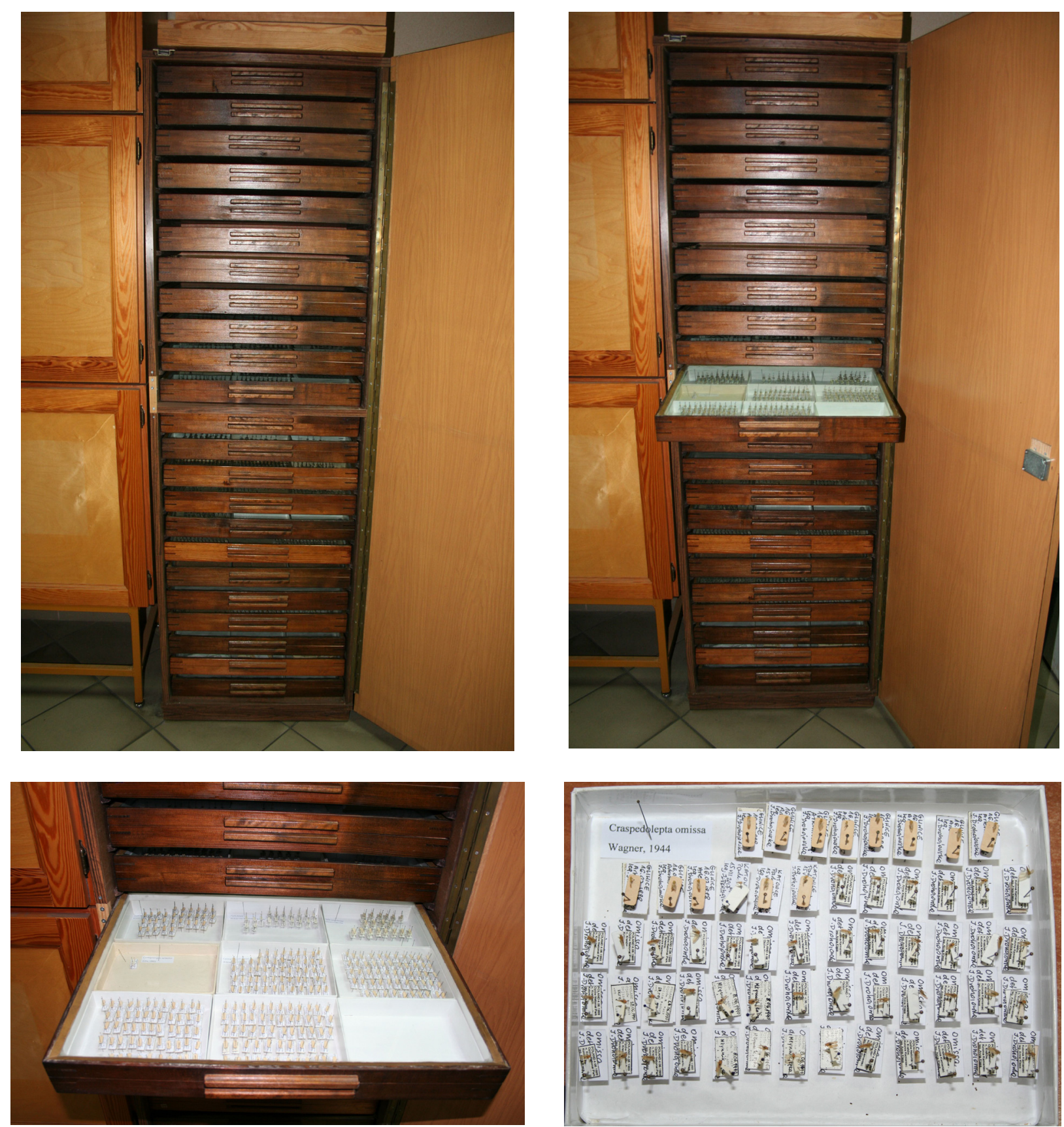

Ryc. 26-29. Szafa z gablotami wypełnionymi okazami koliszków (fot. Jowita Drohojowska).

\section{Owady Namibii}

Zdigitalizowana część kolekcji „Owady Namibii” obejmuje łącznie 2000 okazów (cała kolekcja liczy około 30000 odłowionych okazów), spreparowanych przy użyciu szpilek i kartoników entomologicznych. Kolekcja obejmuje okazy odławiane przy użyciu zarówno standardowego czerpaka entomologicznego, jak i kilku rodzajów pułapek [Barber, pułapki świetlne - światło mieszane oraz UV (Black Light)]. Jedna $z$ najczęściej stosowanych metod, przy użyciu której pozyskano 95\% wszystkich osobników, było nocne odławianie na ekran świetlny. Ostatnia $z$ wymienionych metod okazała się najskuteczniejsza, nie tylko ze względu na mało zróżnicowana szatę roślinną w miejscach odłowu, ale również ze względu na niewielka wilgotność środowiska, powodująca zmniejszona aktywność owadów w okresie, w którym prowadzono badania. Osobniki znajdujace się w kolekcji odławiane były na przełomie pory suchej i deszczowej, tj. od 15 listopada do 16 grudnia 2014 r., w środkowej i północnej części Namibii oraz na terenach przygranicznych Botswany i Zambii. 
Wspomniana ekspedycja entomologiczna rozpoczęła się w stolicy Namibii (Windhoek), a jej trasa przebiegała przez miejscowości lub tereny: Grootfontein, Rundu, Divundu, Katima Mulilo (w tym tereny zalewowe rzek Zambezi i Okavango), Etosha National Park, Outjo, Khorixas, Skeleton Coast National Park, Brandberg i Okahandja, i $z$ tych właśnie lokalizacji, dla których każdorazowo zapisywano koordynaty GPS, pochodza okazy zdigitalizowane $\mathrm{w}$ bazie IMBIO. Pozyskany w trakcie wyprawy materiał stanowia wyłącznie owady $z$ różnych grup taksonomicznych. Należy zaznaczyć, iż przeważająca część okazów stanowią osobniki należące do rzędu Hemiptera (głównie Heteroptera i Auchenorrhyncha). Zdigitalizowana część zbioru reprezentowana jest wyłącznie przez okazy należące do podrzędu Heteroptera (pluskwiaki różnoskrzydłe) i swoim zakresem obejmuje zarówno taksony lądowe, jak i wodne. Niewielka część pozyskanych okazów zabezpieczona została w 99\% etanolu, jako materiał do badań molekularnych (Ryc. 22-25).

\section{DOMINIK CHŁOND}

Kolekcja koliszków (Psylloidea)

Koliszki (Psylloidea) to nieliczna i mało znana grupa pluskwiaków licząca około 3000 gatunków, występujących głównie w rejonach tropikalnych. W Polsce wykazano dotąd zaledwie 113 gatunków. Koliszki często odławiane sa „przy okazji”, podczas badań innych blisko spokrewnionych i znacznie liczniejszych pluskwiaków, np. mszyc, piewików czy skoczków. Najwybitniejszym znawca Psylloidea w Polsce był prof. Sędzimir Maciej Klimaszewski, który przez ponad 40 lat badał tę grupe owadów. Od poczatku swojej pracy, podjętej w 1959 r. w Instytucie Zoologicznym PAN w Warszawie, prowadzac badania terenowe, zbierał okazy koliszków i tworzył ich kolekcję. W wyniku Jego badań powstał bogaty zbiór (około 300 gatunków), o dużej wartości naukowej, będący własnością Muzeum i Instytutu Zoologii PAN, a który przez wszystkie lata pracy Profesora był pod Jego opieka. W 1964 r. prof. Klimaszewski podjał prace na Uniwersytecie Marii Curie-Skłodowskiej w Lublinie, a następnie w 1973 r. na Uniwersytecie Ślaskim w Katowicach. Podczas pracy w tych ośrodkach pojawiła się potrzeba wykorzystywania koliszków do pracy ze studentami. Okazy ze zbioru naukowego MiIZ PAN były zbyt cenne, aby udostępniać je na zajęciach, np. do nauki oznaczania, etykietowania czy preparowania. W zwiazku $\mathrm{z}$ tym, zaczęto gromadzić materiały do pracy dydaktycznej, które zbierane były m.in. podczas zajęć terenowych ze studentami. Były to najbardziej pospolite, najliczniejsze i najłatwiejsze do odłowienia gatunki $\mathrm{z}$ terenu Polski. W tym zbiorze Profesor umieścił także okazy koliszków licznie zebranych przez Niego podczas wypraw naukowych, głównie $z$ terenu Mongolii, oraz część materiałów pozyskanych na drodze wymiany $z$ innymi naukowcami. Od 1998 r. do zbioru zaczęły trafiać gatunki zbierane przez Jowitę Drohojowska, ówczesną magistrantkę, późniejszą doktorantkę prof. Klimaszewskiego, a obecnie samodzielnego pracownika badawczo-dydaktycznego Zespołu Zoologii Instytutu Biologii, Biotechnologii i Ochrony Środowiska. Przez ponad 20 lat pracy i opieki nad tym zbiorem, po każdym sezonie wegetacyjnym, prowadzac m.in. badania terenowe, a także zajęcia terenowe ze studentami, dr hab. Jowita Drohojowska wzbogacała kolekcję o nowe okazy. W tym czasie material ten został przez Nia oznaczony, spisany i uporzadkowany zgodnie z obowiazujaca systematyka tej grupy owadów. Początkowo nieliczny zbiór koliszków przeznaczony do pracy dydaktycznej, utworzony przez prof. Klimaszewskiego, $z$ czasem stawał się coraz liczniejszy i obecnie jest w nim około 3000 oznaczonych okazów, sklasyfikowanych do 240 gatunków reprezentujących 6 rodzin koliszków. W 52\% zebrany materiał został odłowiony przez prof. Klimaszewskiego, w 36\% przez dr hab. Jowitę Drohojowska, natomiast pozostałe okazy $(12 \%)$ pozyskano $\mathrm{w}$ drodze wymiany $z$ innymi naukowcami, bądź zostały zebrane przez studentów.

Jest to tzw. zbiór suchy, a tylko niewielka jego część (5\%) jest w postaci preparatów mikroskopowych. Koliszki, ze względu na niewielkie rozmiary ciała $(1,5-5 \mathrm{~mm})$, nie sa rozpięte na kartonikach entomologicznych (stosowanych najczęściej w kolekcjach muzealnych), lecz sa nabite na minucje, znacznie cieńsze od szpilek entomologicznych. Taki sposób przechowywania okazów jest $z$ pewnościa utrudnieniem dla osoby preparujacej, wymagajacym od niej znacznej wprawy, a ponadto czyni ten zbiór niezwykle podatnym na uszkodzenia. Największa jednak zaleta przechowywania owadów na minucjach jest fakt, że przy wykorzystaniu okazów ze zbioru do dowolnych analiz, np. morfologicznych, owad, oprócz niewielkiego otworu w sternicie tułowia, nie ma żadnych uszkodzeń. Dlatego okazy zgromadzone w tym zbiorze były, i nadal sa, wykorzystywane do różnorodnych analiz i wielu badań, a także do zajęć dydaktycznych, np. pracowni licencjackich, specjalizacyjnych czy magisterskich (Ryc. 26-29).

Wartość dydaktyczna tego zbioru jest nie do przecenienia, natomiast wartość naukowa, w porównaniu $z$ kolekcja MiIZ PAN, jest 


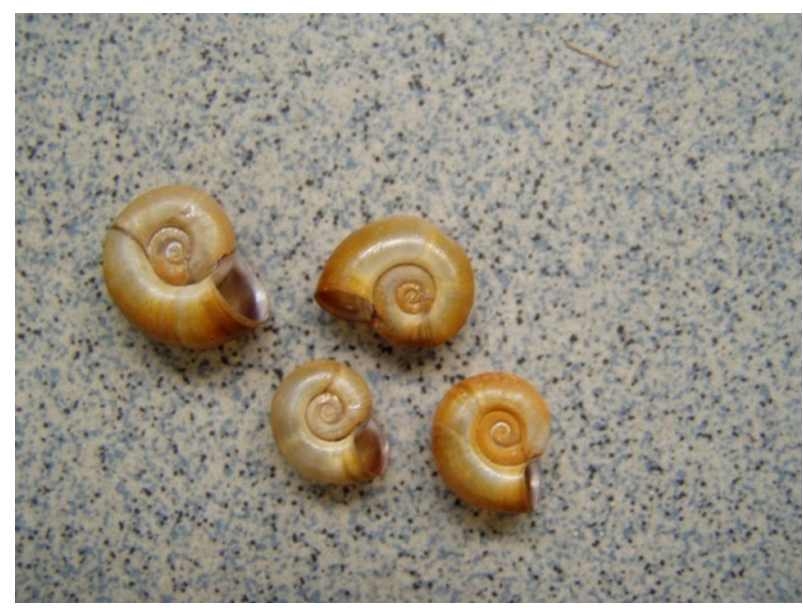

Ryc. 30. Planorbarius corneus - gatunek pospolicie i licznie występujący w zbiornikach antropogenicznych - okazy z kolekcji hydrobiologicznej (fot. Aneta Spyra).

niewielka. Choć w zbiorze nie ma gatunku, którego nie byłoby w kolekcji warszawskiej, a pojedyncze $\mathrm{i}$ nieliczne typy umieszczone $\mathrm{w}$ tym zbiorze to jedynie paratypy (12 okazów), które także reprezentowane sa $\mathrm{w}$ zbiorze MiIZ PAN, to stanowia one zabezpieczenie dla kolekcji warszawskiej.

JOWITA DROHOJOWSKA

Kolekcja pijawek (Hirudinea), skaposzczetów (Oligochaeta) i mięczaków (Mollusca) słodkowodnych

Kolekcja makrobezkręgowców słodkowodnych powstała $\mathrm{w}$ trakcie wieloletnich badan prowadzonych przez pracowników i magistrantów byłej Katedry Hydrobiologii Wydziału Biologii i Ochrony Środowiska Uniwersytetu Ślaskiego w Katowicach. Obecnie Zespół Hydrobiologii kontynuuje proces dydaktyczny i wzbogaca kolekcję o kolejne zwierzęta bezkręgowe. W skład kolekcji wchodza m.in. ślimaki, małże, pijawki i skaposzczety, które sa przechowywane w różny sposób. Pijawki i część ślimaków znajdują się w opatrzonych etykietami probówkach $z$ alkoholem etylowym, część suchych muszli ślimaków i małży umieszczono w opisanych probówkach i pojemnikach, a skaposzczety zamknięte sa $\mathrm{w}$ półtrwałych preparatach w laktofenolu Ammana. Najstarsze okazy w kolekcji maja 30 lat.

Okazy w kolekcji hydrobiologicznej pochodzą głównie ze zbiorników antropogenicznych i cieków wodnych przekształconych na skutek działalności człowieka, położonych na obszarach przemysłowych o różnym stopniu antropopresji, zbiorników miejskich, środowisk wodnych znajdujących się w kompleksach leśnych i wzdłuż ciągów komunikacyj-

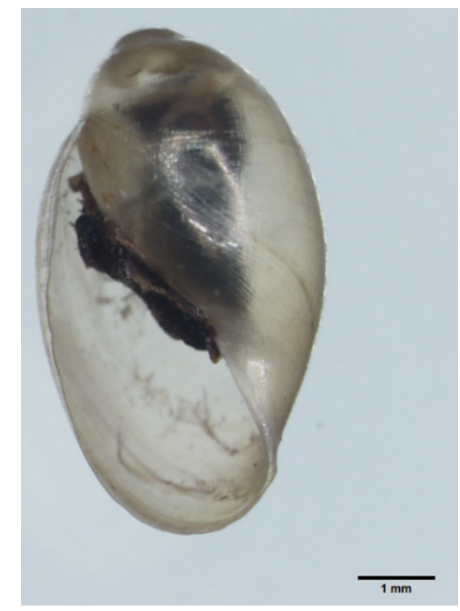

Ryc. 31. Aplexa hypnorum - gatunek nielicznie występujacy w środowiskach antropogenicznych (fot. Anna Cieplok).

nych w województwie ślaskim. Zbiorniki powstałe na skutek działalności przemysłowej stanowia ważny obiekt badań, w związku $z$ ich lokalizacja na obszarach pozostajacych pod wpływem wieloletniej antropopresji. W środowiskach antropogenicznych dochodzi do zniszczenia pierwotnego lub naturalnego ekosystemu, a jego miejsce zajmuja nowe siedliska, najczęściej zwiazane $\mathrm{z}$ działalnościa górnictwa (MolEnda 2013), co ma bezpośredni i pośredni wpływ na skład zasiedlających je biocenoz. Skalę bezpośrednich i pośrednich wpływów człowieka odzwierciedla liczba zbiorników wodnych zinwentaryzowanych na obszarze Wyżyny Katowickiej (1 482 zbiorniki) i w granicach Płaskowyżu Rybnickiego (1 505 zbiorników), których łączna powierzchnia wynosi ponad $20 \mathrm{~km}^{2}$ (RZETAŁA i RZETAEA 2003). Zarówno przekształcone antropogenicznie cieki wodne, jak i zbiorni-

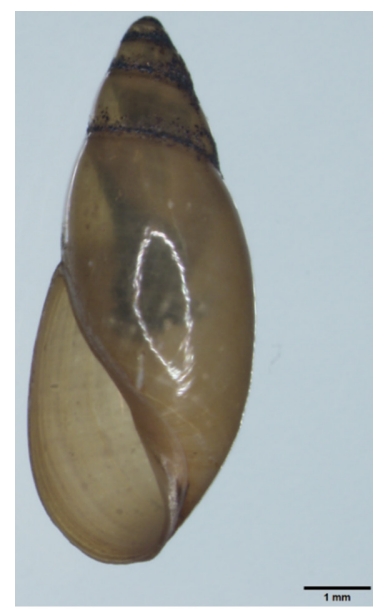

Ryc. 32. Physa fontinalis - gatunek nielicznie występujący w środowiskach (fot. Anna Cieplok). 


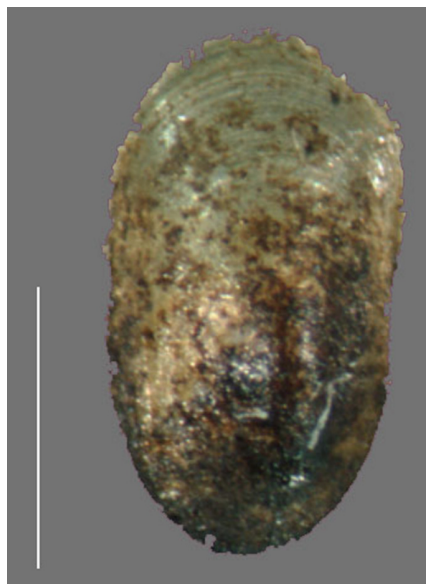

Ryc. 33. Ferrissia fragilis - gatunek obcy w faunie Polski (fot. Anna Cieplok).

ki antropogeniczne często stanowia cenne pod względem przyrodniczym, krajobrazowym i gospodarczym elementy środowiska. Jak wynika $z$ wieloletnich badań (STRZELEC i współaut. 2014, SPYRA i KRODKIEWSKA 2014, KRODKIEWSKA i współaut. 2016, CIEPLOK i SPYRA 2020), siedliska te moga stanowić ostoje dla różnych gatunków mięczaków i pierścienic oraz tworzyć alternatywne biotopy na obszarach, na których nie występuja siedliska naturalne. Wiele osobników w kolekcji pochodzi ze zbiorników zapadliskowych, które sa jednym $z$ najczęstszych obiektów badań. Struktura zasiedlających je zespołów makrobezkręgowców bentosowych, w tym mięczaków, pijawek i skaposzczetów, zmienia sie niejednokrotnie $\mathrm{w}$ ciagu kolejnych lat badań. W kolekcji znajduja się również makrobezkręgowce pochodzace ze zbiorników powyrobiskowych, powstałych w dawnych wyrobiskach popiaskowych (RZETAEA 2008), w których piaszczyste brzegi, powierzchnia i kształt misy, a także sposób zasilania w wodę wywieraja wpływ na faunę denną.

W skład kolekcji ślimaków wchodza głównie gatunki pospolicie i licznie występujace na obszarze Polski m.in.: Planorbis planorbis (Linnaeus, 1758), Bathyomphalus contortus (Linnaeus, 1758), Segmentina nitida (O.F. Müller, 1774), Planorbarius corneus (Linnaeus, 1758) (Ryc. 30), Gyraulus crista (Linnaeus, 1758), Gyraulus albus (O.F. Müller, 1774). Gatunki te skutecznie kolonizują różne środowiska wodne, co uzależnione jest od występowania odpowiedniego podłoża, interakcji biologicznych, preferencji siedliskowych, a także stosunkowo dużej odporności na zmiany właściwości wody (CoSTIL i Clement 1996, Dillon 2000) i okresowe wahania poziomu wody (PIECHOCKI i WAWRZYNIAK-WYDROWSKA 2016). Ze względu na to, że zbiorniki zapadliskowe stanowia

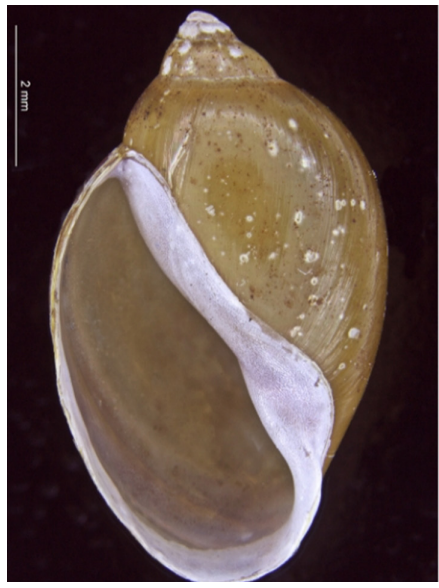

Ryc. 34. Physella acuta - gatunek obcy w faunie Polski (fot. Aneta Spyra).

często siedliska specyficzne pod względem ekologicznym, stwarzają możliwość ich kolonizacji przez gatunki występujace rzadko i na rozproszonych stanowiskach. Do takich gatunków należy Hippeutis complanatus (Linnaeus, 1758). W kolekcji znajda się również okazy gatunków zazwyczaj nielicznie występujacych na terenach przemysłowych, takie jak Aplexa hypnorum (Linnaeus, 1758) (Ryc. 31) i Physa fontinalis (Linnaeus, 1758) (Ryc. 32), a także Bithynia tentaculata (Linnaeus, 1758), gatunku zaliczanego do rzadko występujących ale niezagrożonych $\mathrm{w}$ województwie śląskim (STRZELEC i współaut. 2017). W innych regionach Bithynia tentaculata (Linnaeus, 1758) występuje w różnego typu trwałych zbiornikach wodnych, a pospolicie w dużych wolno płynących rzekach (GLÖER 2002, PIECHOCKI i WAWRZYNIAK-WYDROWSKA 2016). W kolekcji znajduja się również okazy obcych w faunie Polski gatunków małży: Dreissena polymorpha (Pallas, 1771), Corbicula fluminea (O.F. Müller, 1774), Sinanodonta woodiana (I. Lea, 1834) i ślimaków: Ferrissia fragilis (Ryc. 33), Physella acuta (Ryc. 34), Potamopyrgus antipodarum (J.E. Gray, 1843).

W kolekcji pijawek i skaposzczetów znajduja się głównie okazy gatunków charakteryzujacych się szerokim zakresem tolerancji ekologicznej w odniesieniu do czynników środowiskowych, występujące pospolicie w różnego typu środowiskach wodnych m.in.: Helobdella stagnalis (Linnaeus, 1758), Erpobdella octoculata (L.), Glossiphonia complanata (L.), Limnodrilus hoffmeisteri Claparède, 1862 czy Limnodrilus claparedeanus Ratzel, 1868 (KRODKIEWSKA 2003, KRODKIEWSKA i KRÓLCZYK 2011, KRODKIEWSKA i współaut. 2016).

W ramach projektu „Integracja i mobilizacja danych o różnorodności biotycznej Eukaryota $\mathrm{w}$ zasobach polskich instytucji na- 
ukowych (IMBIO)" z kolekcji hydrobiologicznej opracowanych zostanie 4000 rekordów, co stanowi $50 \%$ wszystkich okazów. W bazie znajdą się gatunki małży, ślimaków, pijawek i skąposzczetów. Kolekcja okazów hydrobiologicznych ma dużą wartość dydaktyczną i naukowa.

\section{ANNA CIEPLOK, ADRIANNA KOCZOROWSKA, MARIOLA KRODKIEWSKA, ANETA SPYRA}

\section{Streszczenie}

Rozwój kolekcji i baz danych w zakresie przyrody ożywionej na Uniwersytecie Śląskim jest ściśle związany z ponad 50-letnia historia studiów biologicznych na tej uczelni. Wraz z rozwojem struktury organizacyjnej, pierwotnie Instytutu Biologii, a następnie Wydziału Biologii i Ochrony Środowiska (od 2020 r. Instytutu Biologii, Biotechnologii i Ochrony Środowiska, IBBiOŚ), tworzyły się zespoły badawcze botaniczne i zoologiczne, które w ramach prowadzonych badań, a także indywidualnych zainteresowań pracowników naukowych, gromadziły zbiory i dane przyrodnicze stanowiące materiał badawczy i dokumentacyjny. Zbiory te pochodza przede wszystkim $\mathrm{z}$ badań prowadzonych na terenie regionu śląskiego, jednak $\mathrm{z}$ czasem zostały wzbogacone o zbiory zebrane $\mathrm{w}$ innych regionach kraju, Europy i świata. Kolekcje te maja dużą wartość naukową i dydaktyczna. Zgodnie z ideą współczesnych kolekcji naukowych, celem ich działalności nie jest jedynie gromadzenie i przechowywanie zbiorów, ale udostępnianie i upowszechnianie tej informacji szerokiemu gronu zainteresowanych odbiorców w kraju i na świecie. W ramach projektu IMBIO $z$ kolekcji botanicznych i zoologicznych zostanie udostępnionych łącznie 90500 rekordów, dając możliwość korzystania z zasobów kolekcji IBBiOŚ UŚ na odległość.

\section{LITERATURA}

CiePloK A., SPYRA A., 2020. The roles of spatial and environmental variables in the appearance of a globally invasive Physa acuta in water bodies created due to human activity. Sci. Total Environ. 744, 140928.

Costil K., ClEMENT B., 1996. Relationship between freshwater Gastropoda and plant communities reflecting various trophic levels. Hydrobiologia 321, 7-16.

Dillon R. T., 2000. The ecology of freshwater molluscs. Cambridge Uniw. Press., Cambridge, 509.

GlÖER P., 2002. Die Süsswassergastropoden Nord- und Mitteleuropas, Bestimmungschlüssel, Lebenweise, Verbreitung, Die Tierwelt Deutschlands Begründet 1925 von Friedrich Dahl. 73. ConchBooks Publishing, Hackenheim BRD.

KRODKIEWSKA M., 2003. Leech (Hirudinea) communities of post-exploitation water bodies in industrial region (Upper Silesia, Poland). Pol. J. Ecol. 51, 101-108.

KRODKIEWSKA M., KRÓLCZYK A., 2011. Impact of environmental conditions on bottom oligochaete communities in subsidence ponds (The Silesian Upland, Southern Poland). Int. Rev. Hydrobiol. 96, 48-57.

KRODKIEWSKA M., STRZELEC M., SPYRA A., 2016. Assessing the diversity of the benthic oligochaete communities in urban and woodland ponds in an industrial landscape (Upper Silesia, southern Poland). Urban Ecosyst. 19, 1197-1211.

MolendA T., 2013. Problemy ochrony środowisk antropogenicznych $w$ Polsce. J. Ecol. Health 17, 76-80.

NAWROT M., NAKONIECZNY M., 2019. 50 lat biologii na Uniwersytecie Śląskim. P.P.U.H. PROGRESS sp. $z$ o.o., Sosnowiec

PIECHOCKI A., WAWRZYNIAK-WYDROWSKA B., 2016. Guide to freshwater and marine Mollusca of Poland. Bogucki Wydawnictwo Naukowe, Poznań

ROSTAŃSKI A., GEROLD-ŚMIETAŃSKA I., 2008. Desription and significance of the Herbarium of University of Silesia (KTU). [W:] The importance of natural history museum of taxonomy. BOROWIEC L., TARNAWSKI D. (red). Polish Taxonomical Monographs, Wrocław, 15, 71-84.

ROSTAŃSKI K., KRAWCZYK E., 1993. Zbiory zielnikowe Katedry Botaniki Systematycznej Uniwersytetu Ślaskiego $w$ Katowicach. Annals of the Upper Silesian Museum in Bytom, Natural History 13, 65-73.

RZĘTAEA M., 2008. Funkcjonowanie zbiorników wodnych oraz przebieg procesów limnicznych $w$ warunkach zróżnicowanej antropopresji na przykładzie region górnoślaskiego. Prace Naukowe US, Nr. 2643, 171.

RZETAEA M., RzETAEA M. A. 2003. Origin and evolution of artificial water reservoirs an example of anthropogenic transformation in the geographical environment. [W:] Anthropogenic aspects of geographical environment transformation. Lajos Kossuth University, Silesia University, Debreczyn - Sosnowiec, 73-79.

SPYRA A., KRODKIEWSKA M., 2014. The significance of woodland ponds in the conseration of rare species. A case study of Placobdella costata (F. Müller) (Hirudinea: Glossiphoniidae). Pol. J. Ecol. 61, 613-619.

STRZELEC M., KRODKIEWSKA M., KRÓlCZYK A., 2014. Impact of environment factors on the diversity of gastropods communities in sinkhole ponds in a coal mining region (Silesian Upland, Southern Poland). Biologia 69, 780-789.

STRZELEC M., KRODKIEWSKA M., SPYRA A., 2017. Różnorodność ślimaków słodkowodnych (Gastropoda) $i$ jej zagrożenia $w$ środowiskach wodnych województwa ślaskiego. Regionalne czerwone listy zagrożenia $w$ ochronie zasobów przyrody - ich rola $i$ znaczenie oraz stan $i$ potrzeby. Centrum Dziedzictwa Przyrody Górnego Ślaska, Katowice

TOKARSKA-GUZIK B., CHYBIORZ R., PARUSEL J.B., 2015. Baza danych przestrzennych $w$ zarzadzaniu zasobami środowiska przyrodniczego województwa Ślaskiego. Wyd. Uniwersytetu Śląskiego w Katowicach, Katowice 
KOSMOS Vol. 70, 2, 321-338, 2021

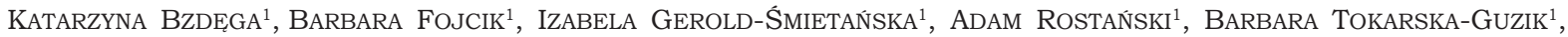

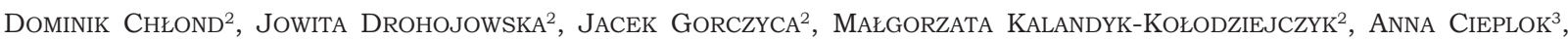
AdrianNa KaCZOROWSKa ${ }^{3}$, Mariola KrodKIEWSKa ${ }^{3}$, ANETA SPYRA ${ }^{3}$

University of Silesia in Katowice, Faculty of Natural Sciences, Institute of Biology, Biotechnology and Environmental Protection,

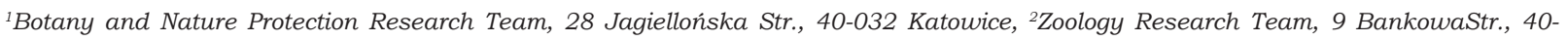
007 Katowice, ${ }^{3}$ Hydrobiology Research Team, 9 BankowaStr., 40-007 Katowice, E-mail: katarzyna.bzdega@us.edu.pl, barbara.fojcik@ us.edu.pl, izabela.gerold-smietanska@us.edu.pl, adam.rostanski@us.edu.pl, barbara.tokarska-guzik@us.edu.pl,dominik.chlond@us.edu.

pl,jowita.drohojowska@us.edu.pl,jacek.gorczyca@us.edu.pl,malgorzata.kalandyk@us.edu.pl,anna.cieplok@us.edu.pl,adrianna. koczorowska@us.edu.pl, mariola.krodkiewska@us.edu.pl, aneta.spyra@us.edu.pl

\section{THE NATURAL SCIENCE DATA AND COLLECTIONS OF THE INSTITUTE OF BIOLOGY, BIOTECHNOLOGY AND} ENVIRONMENTAL PROTECTION OF THE UNIVERSITY OF SILESIA IN KATOWICE

\section{Summary}

The development of collections and databases in the field of animate nature at the University of Silesia is closely related to the over 50-years history of the development of biology at this university. Along with the development of the organizational structure, initially the Institute of Biology, and then the Faculty of Biology and Environmental Protection (from 2020, the Institute of Biology, Biotechnology and Environmental Protection - IBBiOŚ), botanical and zoological research teams were formed, which as part of the conducted research, as well as individual interests of researchers, have been collecting specimens and data that constitute research and documentation material. These collections come mainly from research conducted in the Upper Silesia region, but over time they were enriched with collections gathered in other regions of the country, Europe and the world. These collections are of great scientific and didactic value. According to the idea of modern scientific collections, the purpose of their activity is not only to collect and store collections, but to make this information available and disseminate to a wide group of interested recipients in Poland and around the world. As part of the IMBIO project, a total of 90,500 records will be made available from botanical and zoological collections, making it possible to use the resources of the IBBiOS UŚ collection at a distance.

Key words: data collections, entomofauna, freshwater macroinvertebrates, herbarium, University of Silesia 